\title{
Regionalisation of the Mediterranean basin, a MERMEX synthesis
}

Ayata Sakina-Dorothée ${ }^{1,{ }^{*}}$, Irisson Jean-Olivier ${ }^{1}$, Aubert Anaïs ${ }^{1,2}$, Berline Léo ${ }^{3}$, Dutay Jean-Claude ${ }^{4}$, Mayot Nicolas ${ }^{1}$, Nieblas Anne-Elise ${ }^{5,6}$, D'Ortenzio Fabrizio ${ }^{1}$, Palmiéri Julien ${ }^{4,7}$, Reygondeau Gabriel ${ }^{8}$, Rossi Vincent ${ }^{3,9}$, Guieu Cécile ${ }^{1,10}$

${ }^{1}$ Sorbonne Universités, UPMC Univ Paris 06, CNRS, Laboratoire d'Océanographie de Villefranche (LOV), 06230 Villefranche-sur-Mer, France

${ }^{2}$ National Museum of Natural History, CRESCO, 38 Rue du Port Blanc, F-35800 Dinard, France

${ }^{3}$ Aix Marseille University, University of Toulon, CNRS, IRD, Mediterranean Institute of Oceanography (MIO) UM 110, 13288 Marseille Cedex 09, France

${ }^{4}$ Laboratoire des Sciences du Climat et de l'Environnement LSCE/IPSL, CEA-CNRS-UVSQ, Université Paris-Saclay, 91191 Gif-sur-Yvette, France

${ }^{5}$ Institut français de recherche pour l'exploitation de la mer (IFREMER), UMR MARBEC, Avenue Jean

Monnet, BP171, 34203 Sète, France

${ }^{6}$ CAP RUN - Hydrô Réunion, Magasin n¹0, Darse de pêche, 25 hauturière, Port Ouest, 97420 Le Port, Île de la Réunion, France

${ }^{7}$ Southampton University - National Oceanography Center (NOC), Waterfront Campus, European Way, Southampton SO14 3ZH, UK

${ }^{8}$ Nippon Foundation-Nereus Program and Changing Ocean Research Unit, Institute for the Oceans and Fisheries, University of British Columbia. Aquatic Ecosystems Research Lab. 2202 Main Mall.

Vancouver, BC V6T 1Z4, Canada

${ }^{9}$ IFISC (Institute for Cross-Disciplinary Physics and Complex Systems), CSIC-UIB, Palma de Mallorca

07122, Spain

${ }^{10}$ Center for Prototype Climate Modeling, New York University Abu Dhabi, P.O. Box 129188, Abu

Dhabi, United Arab Emirates

*Corresponding author : Sakina-Dorothée Ayata, email address : sakina.ayata@normalesup.org

\begin{abstract}
:
Regionalisation aims at delimiting provinces within which physical conditions, chemical properties, and biological communities are reasonably homogeneous. This article proposes a synthesis of the many recent regionalisations of the open-sea regions of the Mediterranean Sea. The nine studies considered here defined regions based on different, and sometimes complementary, criteria: dynamics of surface chlorophyll concentration, ocean currents, three-dimensional hydrological and biogeochemical properties, or the distribution of organisms. Although they identified different numbers and patterns of homogeneous regions, their compilation in the epipelagic zone identifies nine consensus frontiers, eleven consensus regions with relatively homogeneous conditions, and four heterogeneous regions with highly dynamical conditions. The consensus frontiers and regions are in agreement with well-known hydrodynamical features of the Mediterranean Sea, which constrain the distribution of hydrological and ecological variables. The heterogeneous regions are rather defined by intense mesoscale activity. The
\end{abstract}


synthesis proposed here could constitute a reference step for management actions and spatial planning, such as the application of the European Marine Strategy Framework Directive, and for future biogeochemical and ecological studies in the Mediterranean Sea.

\section{Highlights}

- Synthesis of nine previous regionalisations of the epipelagic Mediterranean Sea. Nine congruent frontiers, related to circulation and bathymetry. Eleven congruent homogeneous regions, related to large scale circulation. Four heterogeneous regions, associated with dynamical mesoscale circulation. A key step for future spatial planning in scientific studies and marine management.

Keywords: Mediterranean Sea, regionalisation, biogeochemistry, circulation, mesoscale features, epipelagic ocean, management, spatial planning 


\section{Introduction}

Marine ecosystems and associated services are subject to strong climatic and anthropogenic changes. This is especially true in the Mediterranean Sea (Bianchi and Morri, 2000; Coll et al., 2010), due to both its configuration as a semi-enclosed sea and its high and increasing concentration of human activities (Lejeusne et al., 2010; The Mermex Group, 2011). However, the absence of a consensus of its geographical framework complicates the description, management and conservation of Mediterranean marine ecosystems (Coll et al., 2012). Such a regional framework should rely on regionalisation, or the objective definition of ecological and biogeochemical spatial units. Historically, the Mediterranean Sea has been subdivided into geographical entities (Figure 1) whose limits were set according to geographical frontiers (such as straits) or political delineations. In the 90's, remote sensing allowed to 
describe the dynamics of primary production, which was used to delineate provinces within basins (Sathyendranath et al., 1995) and then in the global ocean (Longhurst, 1998; Oliver \& Irwin, 2008). In Longhurst's classification, the Mediterranean Sea was distinguished from other regions, without further separation within the system, despite its apparent heterogeneity. Later, a new global system was proposed by Spalding et al. (2007) for coastal and shelf areas: the Marine Ecoregions of the World (MEOW). This biogeographical classification, based on existing global and regional literature, describes a nested system of 12 realms, 62 provinces, and 232 ecoregions. In this framework, the Mediterranean Sea represents a province of the "Temperate Northern Atlantic" realm and is subdivided into seven ecoregions: the Adriatic Sea, the Aegean Sea, the Levantine Sea, the Tunisian Plateau/Gulf of Sidra, the Ionian Sea, the Western Mediterranean, and the Alboran Sea (Figure 2A). This regionalisation of the Mediterranean Sea corresponds mostly to classical geographical entities but constitutes a first regionalisation attempt that could be used for regional planning. Indeed, its delineations are clear and correspond to different sub-basins with potentially distinct hydrodynamical, hydrological, biogeochemical, and ecological characteristics. However, regionalisation should rather be based on objective criteria for identifying and defining regions with similar characteristics.

In other parts of the world ocean, regionalisation mainly focused on mapping marine habitats, defined as "a recognizable space which can be distinguished by its abiotic characteristics and associated biological assemblage, operating at particular spatial and temporal scales" (ICES, 2005). Although this definition is well-adapted for benthos, it may be more difficult to apply it to the pelagos (Costello, 2009). Nevertheless, some areas have benefited from tremendous efforts in mapping and documenting pelagic habitats (or seascapes), such as the Austral Ocean (Raymond et al., 2014) or the seas around Australia (Commonwealth of Australia, 2006). Isolated studies have also documented typologies of hydrological structures and pelagic communities at smaller scale, such as in the Bay of Biscay (Planque et al., 2006) or in the English Channel (Delavenne et al., 2013).

In the Mediterranean Sea, several studies have proposed such objective regionalisations by using statistical clustering applied to various variables describing the open waters (Table 1). Briefly, D'Ortenzio and Ribera d'Alcalà (2009), Palmiéri (2014), and Mayot et al. (2016) focused on phytoplankton phenology; Nieblas et al. (2014) and Reygondeau et al. (2017) used climatological averages of key biogeochemical variables (such as temperature, salinity, nutrient concentrations, etc.); Berline et al. (2014), Nieblas et al. (2014), and Rossi et al. (2014) used the hydrodynamical properties of surface water masses; Reygondeau et al. (2014) used the composition of biological communities, inferred from the modelled habitats of marine species over the basin (each study is described in greater detail in the next section). This high publication rate (eight regionalisation studies in eight years) reveals a strong focus on the Mediterranean Sea compared to other regions of the world. The Mediterranean Sea seems like a good study case because it can be seen as a "miniature ocean [that] can serve as a giant mesocosm of the world's oceans" (Lejeusne et al., 2009). Indeed, some of the main features of the global ocean, such as a thermohaline circulation influenced by climate and dense water formation, are represented over 
smaller spatial scales in the Mediterranean Sea (Bethoux et al., 1999). In addition, the Mediterranean region is a hotspot for climate change (The Mermex Group, 2011) and holds high stakes for biodiversity conservation (Coll et al., 2010). A consensus regionalisation of the Mediterranean Sea is currently missing, while it could not only synthesise our knowledge of this basin but also help our understanding of marine ecosystem at global scale, especially in semi-enclosed seas.

In that context, the Work Package 5 of the French research program MERMEX (https://mermex.mio.univ-amu.fr/?page $i d=1663$ ) was a transversal action that seeked to synthesize existing hydrographical, hydrological, biogeochemical, and ecological data in the Mediterranean Sea and to put this knowledge in the context of the multiple natural and anthropogenic pressures acting on the Mediterranean Sea. The present work is a contribution of this MERMEX WP5 and aimed to compare these different regionalisations of the Mediterranean Sea and to propose a synthesis that could be used to inform management decisions as well as for future biogeochemical and ecological studies. We focus on surface, open waters only. While Mediterranean coasts are heavily populated, the previous basinscale regionalisations did not consider the very coastal areas and, therefore, they cannot be considered here either. Furthermore, they are obviously influenced by localised pressures (riverine inputs, impacts from cities and harbours such as pollution, fishery activities, etc.) and dedicated regionalisations need to be performed at a more pertinent, smaller scale (e.g., Muñoz et al., 2015, for the Gibraltar Strait; or Hattab et al., 2015, for coastal fishes). Similarly, most previous studies focused on the epipelagic domain, probably because it comprises the euphotic zone, where primary production occurs. Most human activities are also concentrated at the surface (Micheli et al., 2013a) and strongly affect the epipelagic ocean. Finally, only one regionalisation has considered the layers below the epipelagic zone and it has showed that the forcing variables (hence the regions) are different among vertical layers (Reygondeau et al., 2017).

The central questions we want to address are: Where do those recent regionalisations agree or disagree? What consensus regionalisation can we propose? How can we link this synthetic view with the structure and functioning of the Mediterranean Sea? To answer these questions, we will review the methods and data used for these regionalisations, quantify the congruence of their frontiers, and propose a new synthetic regionalisation. The following points will then be discussed: What is the interest of considering a consensus regionalisation? How can it be used by scientists and by managers? What are the scientific bottlenecks and the future directions for regionalisation of the Mediterranean Sea? What could be transferred to larger scale regionalisation efforts? 


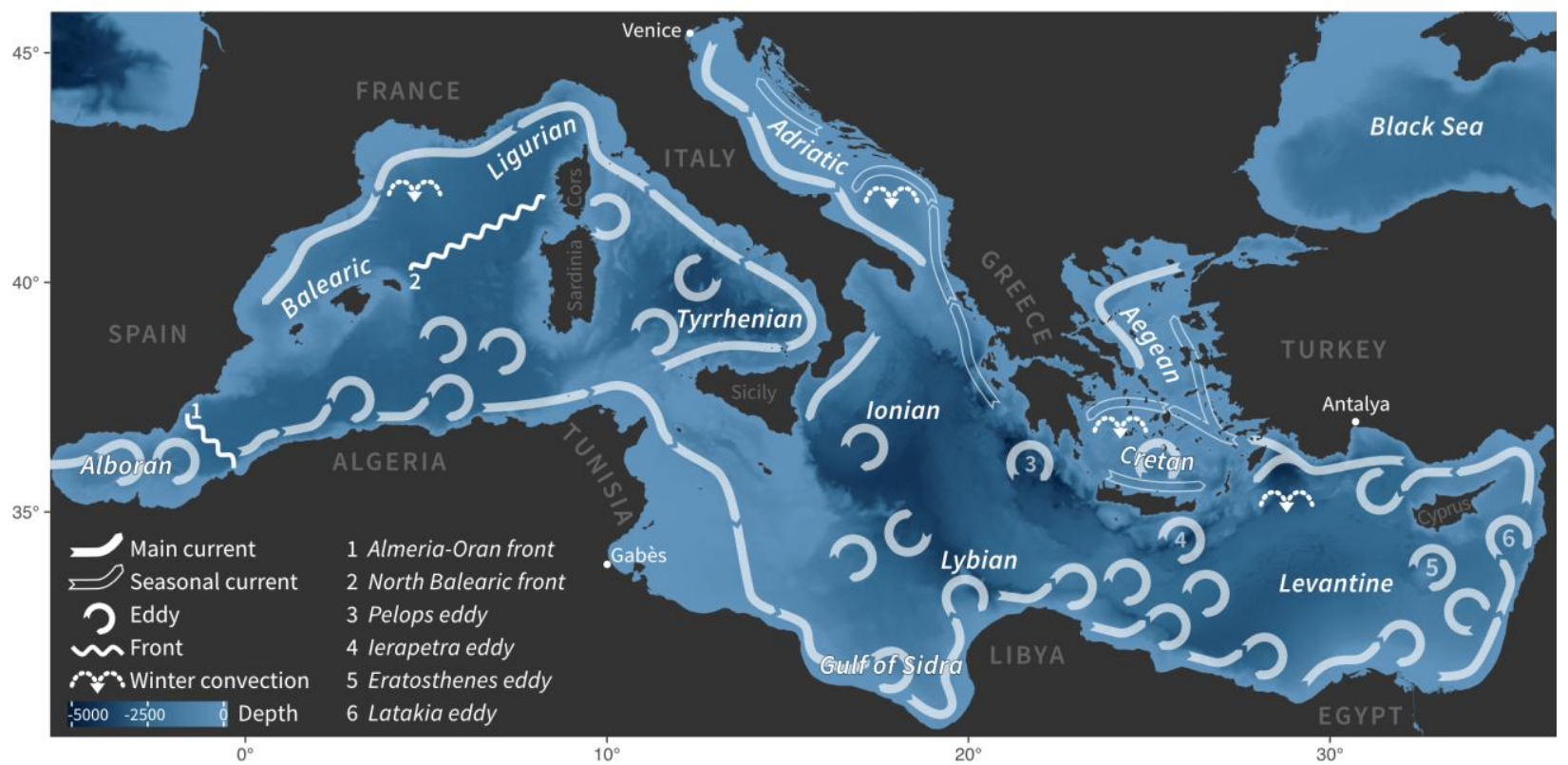

Figure 1: Map of the Mediterranean region displaying the main seas, locations, and surface circulation features, with a special focus on those cited in the text (circulation redrawn from Millot and TaupierLetage, 2005).

\section{Previous regionalisations}

The first statistical regionalisation of the Mediterranean Sea was proposed by D'Ortenzio and Ribera d'Alcalà (2009) (Table 1). Regions were separated according to the phenology (seasonal cycle) of surface chlorophyll concentration. A non-spatial clustering algorithm (k-means) was used to group pixels according to weekly climatologies computed from 10 years of satellite ocean colour data. Seven "trophic" regimes were identified and coherent spatial patterns matched well-known oceanographic structures of the basin, notably the dichotomy between the regions with and without a phytoplankton bloom. The limits of this approach were mainly related to the inherent errors of ocean colour data (algorithmic errors, cloud coverage and the restriction to the surface layer of the ocean), in addition to the limited duration of the time-series (10 years from 1997 to 2007).

Mayot et al. (2016) recently revisited the same approach but added six years of data and analysed interannual variability in addition to climatologies (Figure 2B, Table 1). Doing so, they detected new trophic regimes, corresponding to extreme scenarios that are not observed with climatological averages. Over the 16 years studied, the seven initial trophic regimes were still the most recurrent (Figure 2B, coastal bloom: orange; bloom: blue; moderate bloom: red; no-bloom: purple, green, and light yellow). Their mean spatial distribution was similar to that identified by D'Ortenzio and Ribera d'Alcalà (2009), but with important interannual variability at regional scales. These differences were related to deep convection events in winter, frontal instabilities, inflow of Atlantic or Black Sea Waters and river runoffs. 
Palmiéri (2014) used a similar regionalisation technique but applied it to the output of a threedimensional coupled hydrodynamical-biogeochemical model. They defined and compared the bioregions derived from the phenologies of simulated surface chlorophyll, vertically-integrated chlorophyll ( $\mathrm{Ch}_{\text {tot }}$, Figure 2C, Table 1) and vertical maximum chlorophyll, as well as those derived from mixed layer depth and vertically-integrated phytoplankton biomass. The surface regionalisation was relatively similar to that described by D'Ortenzio and Ribera d'Alcalà (2009) and Mayot et al. (2016), with bloom regions driven by deep mixed layers (D’Ortenzio et al., 2005, Lavigne et al., 2013). Differences were observed with regionalisations that took into account the deep chlorophyll maximum, which is an important characteristic of the Mediterranean Sea, that are missed by satellite imagery, and could be related to the seasonal penetration of solar radiation and vertical nutrient availability. The main limitation of this study was the difficulty to validate the subsurface results of the biogeochemical model at regional scale and hence to test the robustness of the proposed regionalisation.

In a similar three-dimensional approach, using data rather than models, Reygondeau et al. (2017) proposed 60 biogeochemical regions in the Mediterranean Sea: 12 for the epipelagic layer (Figure 2D, Table 1), 12 for the mesopelagic layer, 13 for the bathypelagic layer and 26 for the seafloor layer. Regions were delineated through a consensus between several clustering algorithms applied to climatologies of 16 hydrological and biogeochemical variables averaged per layer. These results confirmed that the classical set of environmental variables used in previous studies (temperature, chlorophyll concentration, mixed layer depth) described well the western-eastern gradient in the surface Mediterranean Sea and were sufficient to partition the epipelagic layer. Their influence decreased with depth, and other variables drove the regionalisation in deeper layers (dissolved oxygen and $\mathrm{PO}_{4}$ concentrations, thermocline depth, etc.). The main limitations of this study were the scarcity of data in the south-eastern Mediterranean and the use of climatologies, erasing seasonal and interannual variability.

In 2014, three regionalisation studies explicitly took into account the ocean dynamics, either using simulated ocean currents or mesoscale ocean features estimated from satellite data. Two studies defined regions solely based on their connectivity due to ocean currents (Berline et al., 2014; Rossi et al., 2014) and another used both biogeochemical and mesoscale variables to delineate regions (Nieblas et al., 2014).

Berline et al. (2014; Figure 2E, Table 1) defined a grid over the whole basin, simulated the advection of particles from every cell of the grid for a year, and computed the mean connection time between each pair of grid cells. This mean connection time was taken as the distance measure for the hierarchical clustering algorithm. This algorithm led to 21 regions that were coherent with the patterns and time scales of general surface ocean circulation. The main limitation of this work was the relatively arbitrary cut-off level of the dendrogram, which was eventually chosen to yield the maximum number of regions that the authors could interpret. 
Rossi et al. (2014) aimed at subdividing the seascape in distinct hydrodynamical provinces to characterize connectivity through larval dispersal at basin-scale (Figure 2F, Table 1) and to inform the design of marine reserves. To do so, they tracked passive Lagrangian particles (a model for larval transport) and constructed Flow Networks (Ser-Giacomi et al., 2015) that were analyzed using their connectivity (or adjacency) matrices. While Rossi et al. (2014) used probabilities of transport instead of mean connection times, contrasting Berline et al. (2014)'s study, the frontiers of these hydrodynamical provinces also matched oceanographic features at various scales (e.g., large-scale circulation patterns as well as mesoscale fronts, jets, eddies). Note that an important difference between both studies is the constraints imposed by their clustering algorithms: the hierarchical clustering algorithm used by Berline et al. (2014) aims at minimizing the exchange among distinct provinces whereas the Infomap algorithm used by Rossi et al. (2014) simultaneously maximizes intra-connectivity and minimizes interconnectivity. The main limitation of both studies was that they only considered passive tracers advected in two-dimensional current fields, omitting the 3-dimensionality of the flow and more complex larval behaviour (vertical migration, mortality, and settlement). As such, they both described hydrodynamical connectivity rather than biological connectivity.

Nieblas et al. (2014) used monthly climatologies of variables classically used for regionalisation (i.e., sea surface temperature, surface chlorophyll, and bathymetry), and also mesoscale characteristics (i.e., eddy kinetic energy, finite-size Lyapunov exponents, and surface frontal gradients) to describe the surface ocean. Through k-means partitioning, the authors identified four biogeochemical regions in the Mediterranean Sea when considering "classical" variables, four regions when considering mesoscale features, and five regions when combining classical and mesoscale features (Figure 2G, Table 1). Overall, the classical regionalisation had the most stable boundaries in time and space, while the boundaries for the mesoscale and combined arrays were highly variable. This indicated that the apparent stability found from classical variables only is not representative of the "true" in situ variability of the oceanic environment. Interestingly, the addition of mesoscale features to biogeochemical variables was important to further delineate regions in the open ocean, which would otherwise seem homogeneous. Several oceanographic variables were included to capture as much of the ocean variability and dynamics as possible; however, the analysis indicated that some variables may be redundant and the authors suggested that future analyses could be streamlined to include fewer, non-redundant features. 
Finally, Reygondeau et al. (2014) proposed an ecoregionalisation, which takes into account the biological components of Mediterranean Sea ecosystems. They used ecological niche modelling to project the potential distribution of over 800 marine species, distributed across all trophic levels (primary producer, primary consumer, secondary consumer, top predator; Table 1). These modelled communities were clustered into regions with the same multi-algorithm approach as Reygondeau et al. (2017), applied to each trophic level. Finally, these regions per trophic level and the biogeochemical regions of Reygondeau et al. (2017) were merged into 25 ecoregions, or 15 ecoregions when using only pelagic layers (used here, Figure $2 \mathrm{H}$ ). This work proposed an end-to-end approach based on biotic variables, but was limited by the low number of occurrences recorded in international databases, on which the ecological niche models were constructed, especially for lower trophic level species (primary producers and primary consumers). In addition, only Mediterranean occurrences were considered, even for species distributed elsewhere, and this regional calibration might have resulted in truncated environmental niches.

\section{Methods}

To analyse comparable regionalisation efforts with statistical tools, to avoid over-representing some processes, and to propose a synthetic view, only epipelagic regions estimated from non-redundant data were kept. It means that when several regionalisations were proposed using the same datasets, only the regionalisation taking into account the highest number of environmental predictors was kept. Following these criteria, the regionalisation based climatologies in Mayot et al. (2016) was considered an update of the original work by D'Ortenzio and Ribera d'Alcalà (2009) and replaced it. The other regionalisation in Mayot et al. (2016), focusing on interannual variability, was largely similar and not considered. In Palmiéri (2014), only the regionalisation based on chlorophyll vertically-integrated over the euphotic zone was kept because it captured the patterns of their other regionalisations based on the depths of the mixed layer or of the deep chlorophyll maximum, while their surface-only approach was close to that of Mayot et al. (2016). Only the epipelagic bioregionalisation proposed by Reygondeau et al. (2017) was included. From Rossi et al. (2014), only the regionalisation for a drifting duration of 30 days was used, because it is representative of the duration of the larval stage of many species of fish, which this study focussed on (Macpherson and Raventos, 2006). The "full" regionalisation of Nieblas et al. (2014) that combined both classical and mesoscale features was preferred to the regionalisations based separately on "classical" and "mesoscale" features. In Reygondeau et al. (2014), regionalisations involving benthic data were not used in our analysis. Finally, eight regionalisations were considered (Figure 2): Spalding et al. (2007), Mayot et al. (2016) using climatologies, Palmiéri (2014) using verticallyintegrated simulated chlorophyll concentration, Reygondeau et al. (2017) using only the epipelagic regionalisation, Berline et al. (2014), Rossi et al. (2014) with their shortest drifting duration (30 days), Nieblas et al. (2014) considering the full regionalisation including both biogeochemical and mesoscale variables, and the pelagic ecoregionalisation of Reygondeau et al. (2014). 
To help this synthesis, regions from all studies needed to be superposed to detect which zones are consistently delineated as a region by all approaches. To do so, regionalisations needed to be homogenised prior to comparison. Regionalisations based on ocean currents defined many more regions than the others (Table 1). To avoid giving these an over-estimated weight in our analysis, since having more regions means having more frontiers, the number of regions was reduced. In Berline et al. (2014), the hierarchical dendrogram used to identify regions was simply cut higher, to yield 15 , more consistent, regions. In Rossi et al. (2014), small regions (<20 pixels for a full domain of 3665 pixels) were removed, resulting in 30 regions. The clusters of Berline et al. (2014) and Rossi et al. (2014) are contiguous as a consequence of the connectivity based distance used, while other regionalisations defined fewer, but geographically discontiguous clusters (Table 1). Overall, the actual number of geographical "patches" is quite similar among regionalisations. For example, Nieblas et al. (2014) only defined five clusters, but those are distributed in about 15 distinct geographical patches (Figure 2). Here we are interested in the frontiers between clusters, i.e. in their geographical distribution, not in the number of clusters per se.

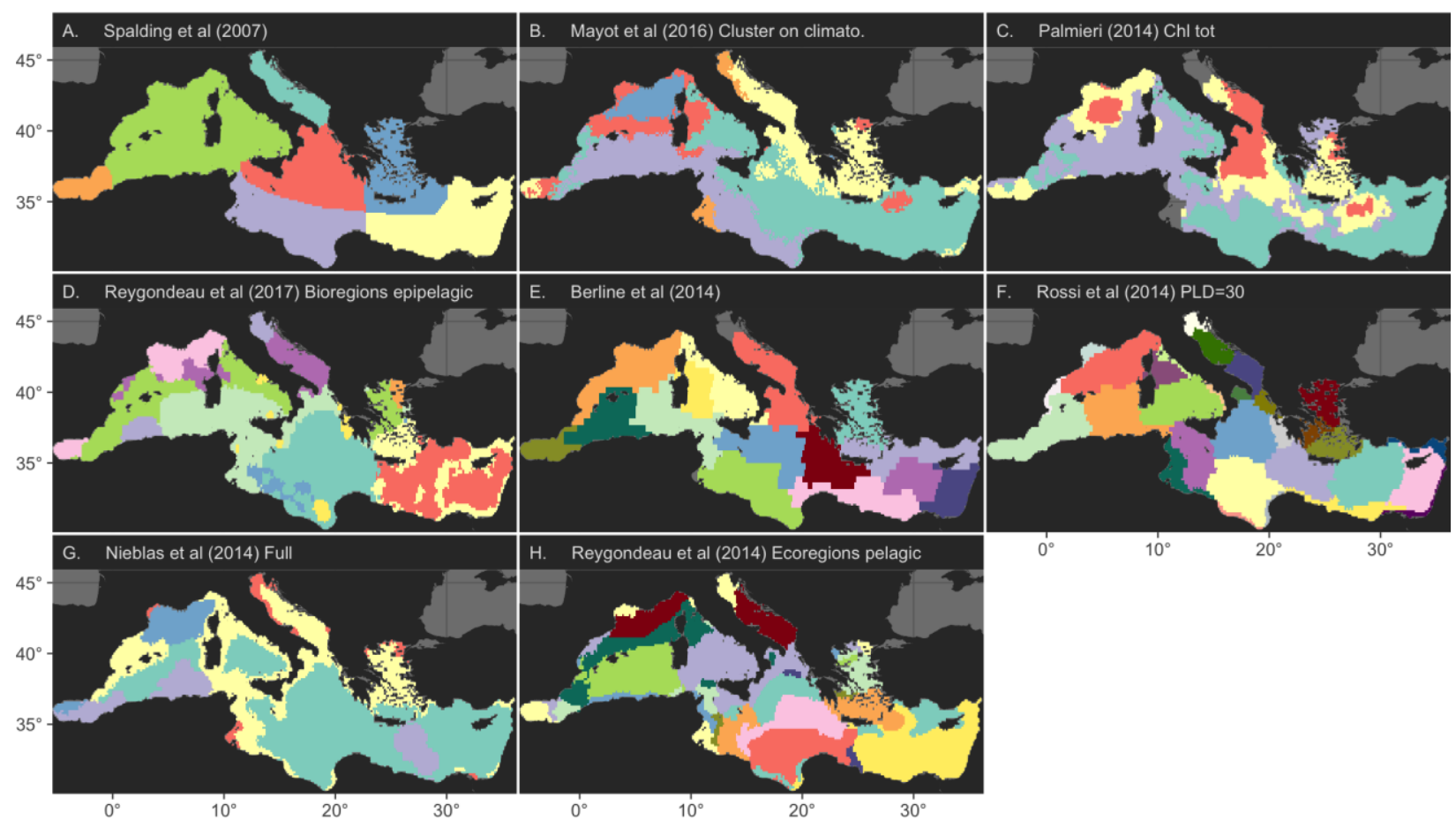

Figure 2: Representation of the eight regionalisations of the Mediterranean Sea compared in this study (post-processed for clarity, as described below). Colours are used to differentiate regions; they have no special meaning among panels. These maps (and all the following ones) can be explored interactively at https://mermexregio.obs-vlfr.fr. 
All regionalisations were re-gridded over a $0.15 \circ$ grid $(\sim 15 \mathrm{~km})$ through nearest neighbour interpolation. The resolution of $0.15^{\circ}$ was chosen as a compromise among the resolutions of all studies (four higher, four lower; Table 1) that captured mesoscale patterns, but kept some basin-scale generality (Sup Figure 2). To focus on the pelagic Mediterranean Sea, all pixels outside of the Mediterranean or within 0.05응 $(\sim 5 \mathrm{~km})$ of the coasts were removed.

Many regionalisations, in particular those based on satellite-derived chlorophyll, were quite noisy. They featured convoluted borders and/or small, discontiguous regions. The regionalisations were denoised to clarify basin-scale patterns, and simplify the superposition of the regionalisations. Technically, for each regionalisation, the proportion of each cluster was systematically calculated within a $7 \times 7$ pixel shifting window $\left(\sim 1^{\circ} \times 1\right.$ ) over the whole domain. The majority cluster was assigned to the pixels whose cluster represented less than $20 \%$ of the window. This majority filter was applied recursively. When fewer than 200 pixels changed (among $>10,000$ pixels for the entire Mediterranean Sea, after regridding), the window was downsized to $3 \times 3$ pixels, to focus on removing speckles. When fewer than 50 pixels changed, filtering stopped.

These steps resulted in easy to compare regionalisations, while retaining their original characteristics (Sup Figures 1, 2, and 3; Figure 2). For each, the frontiers or borders between regions were detected and all frontier maps were summed, thus computing the congruence between those regionalisations (Figure 3). A pixel which is never a frontier has the value 0 in the congruence map; a pixel which is a frontier in all regionalisations has the value 8 . Several weighting schemes were tested; frontiers of each regionalisation were scaled by the number of clusters, the number of geographical patches, and the number of frontier pixels. Since the general aspect of the maps was either similar to Figure 3 or completely dominated by one regionalisation, the simple sum was used.

Regions that are consensual among studies translate into areas with no or few frontiers at their core (low congruence of frontiers) and many frontiers at their edge (high congruence). To detect those objectively, the congruence map was smoothed to erase thin and weak frontiers (only one regionalisation cut there) and keep thin and strong frontiers (several regionalisations cut there) as well as weak but wide frontiers (several regions delineated at approximately the same location). A gaussian moving window of radius 0.5 ( $(\sim 50 \mathrm{~km})$ was used. On this smoothed map (Figure 4), cores of low congruence were detected (smoothed congruence $<0.02$ ) and extended to the contour line 0.3 to define consensus regions. Cores of high congruence (smoothed congruence $>0.98$ ) were detected and extended to the isoline 0.8 to define consensus frontiers zones. These frontier zones were reduced to actual consensus frontiers by delineating the ridges of the smoothed congruence surface inside each zone. A "catchment area" map was computed using a triangular flow model (i.e. simulating water flowing along the congruence map, albeit towards high congruence values); high catchment values were considered to be ridges. Consensus regions and frontiers were well defined and were not very sensitive to the choices of smoothing parameter or contour limit (Sup Fig 4). 
Manipulation of geographical layers to delineate frontiers was performed with QGis version 2.12 (QGIS Development Team, 2009). All other data analysis and maps were done in R version 3.3.2 (R Core Team, 2015). The web application to display results at https://mermexregio.obs-vlfr.fr is powered by shiny (https://shiny.rstudio.com) and leaflet (http://leafletjs.com). Colours are extended from Harrower and Brewer (2003). All code and data are available at https://github.com/jiho/mermexregio.

\section{Results and discussion}

\subsection{Consensus frontiers}

Although the different regionalisations do not often agree on frontier location at the pixel scale (maximum frontier congruence of 5; Figure 3), some areas are characterised by high frontier congruence and correspond to consensus frontiers (Figure 4).

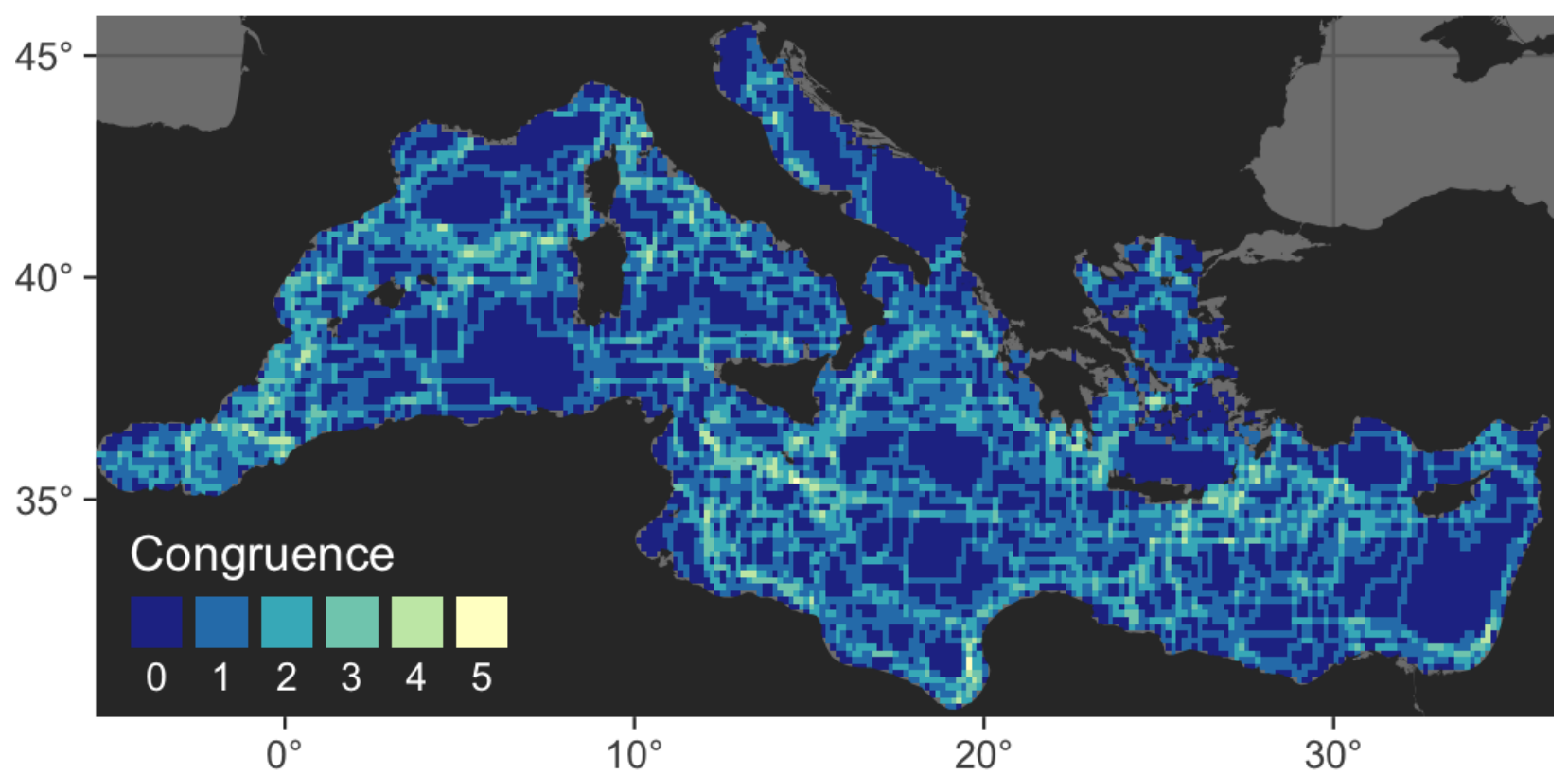

Figure 3: Map of the congruence of frontiers among regionalisations. The colour scale depicts the number of regionalisations that define a given pixel as a frontier between two regions. If all regional frontiers agree, the frontier congruence value would be 8 ; the maximal observed frontier congruence value was 5 . 


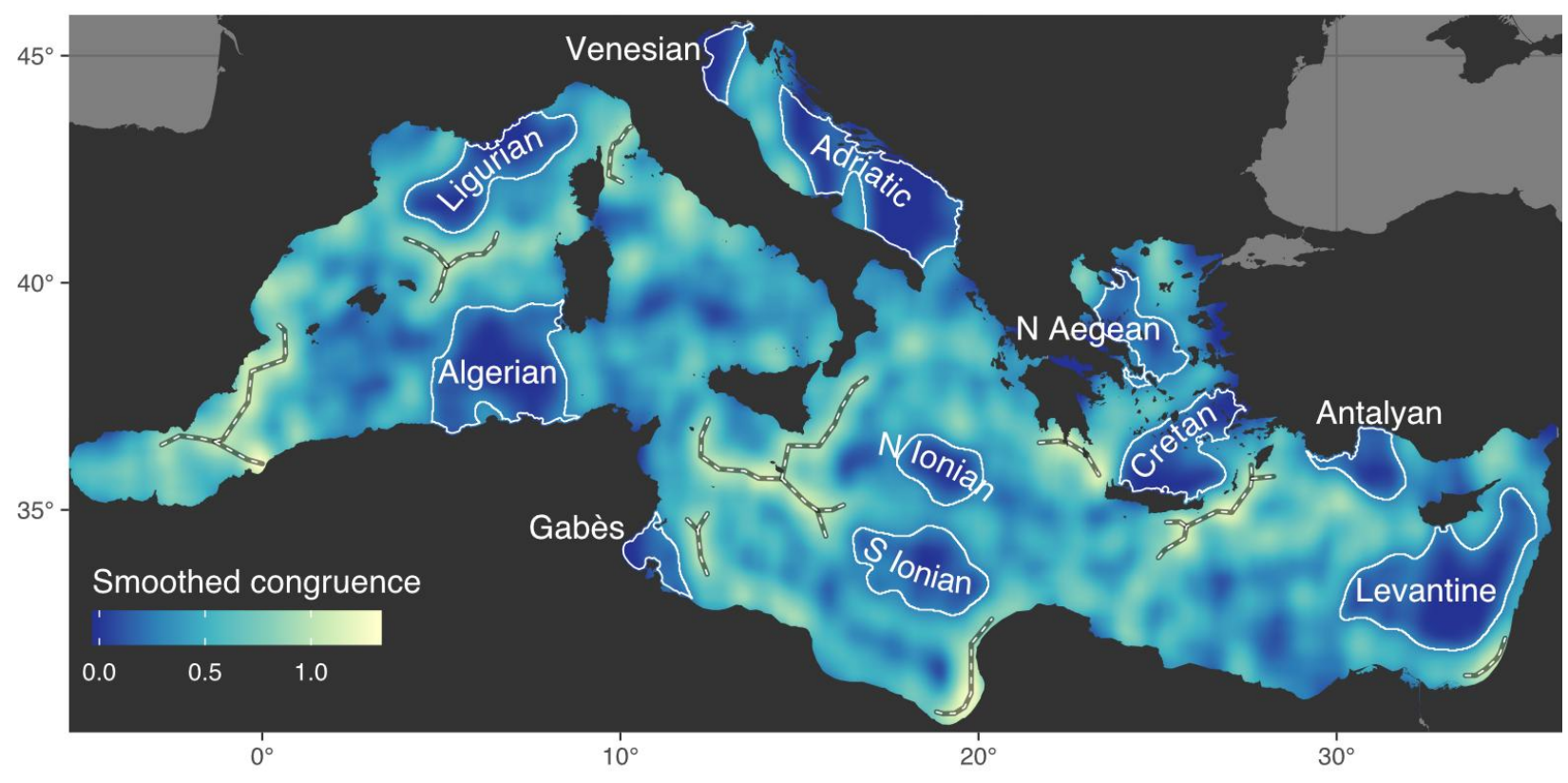

Figure 4: Map of smoothed frontier congruence overlaid with the eleven consensus regions (white polygons), defined as having a low congruence core and being surrounded by strong frontiers, and the nine consensus frontiers (dashed lines), defined as having a high congruence core and some spatial extent.

About half of these consensus frontiers may be related to hydrodynamical discontinuities that result in strong gradients of hydrological and biogeochemical properties (Figure 1; Millot, 1999; Millot and Taupier-Letage, 2005). The Almeria-Oran front, at the eastern edge of the Alboran Sea, is associated with filament formation and elevated phytoplankton concentration (Prieur and Sournia, 1994; Davies et al., 1993), high primary production (Videau et al., 1994), and secondary production (Youssara \& Gaudry, 2001). The North Balearic front, between the Balearic Islands and Sardinia, is a thermal front whose exact location may vary with wind conditions (Lopez-Garcia et al., 1994) and is associated with moderate bloom conditions (Mayot et al., 2016). Additionally, congruence is high along most of the coasts, particularly off Libya, depicting the highly dynamical currents -permanent or seasonal- that affect surface waters and follow a counterclockwise circuit along the continental slopes through both basins (Figures 1B and 3; Millot and Taupier-Letage, 2005).

The other half of the frontiers seems related to strong bathymetric gradients: between Corsica and Italy, south of Sicily, and around Crete (Figures 1 and 4). Although bathymetry was included only in the regionalisation of Nieblas et al. (2014) and not in the others, it seems to strongly control the ocean circulation and thus to condition the structure of water masses, whose properties then defined the regions. It is interesting to note that, although the western and the eastern Mediterranean basins are often considered to be separated by the shallow waters of the Sicilian Strait, our analysis reveals that the main frontier in terms of water masses is more westerly, just before the bottom slopes down again. 


\subsection{Consensus regions}

Other areas are consistently identified as regions by all studies, and are therefore never delineated (i.e., frontier congruence $=0$; Figure 3 ). Based on the smoothed congruence map, eleven such consensus regions could be identified, named after their geographical position, from north-west to south-east (Figure 4): the Ligurian Sea and its eastern extension, the eastern Algerian Sea, the Gulf of Gabes, the Venetian shelf, most of the Adriatic Sea, the central northern Ionian Sea, the central southern Ionian Sea, most of the north western Aegean Sea, the Cretan Sea, the Gulf of Antalya and its offshore extension, and the eastern Levantine Sea. Although most regionalisations of the Mediterranean Sea are based on climatologies and average several years of data, some rely on the temporal dynamics of key biogeochemical variables, such as the phenology of phytoplankton ( $D^{\prime}$ Ortenzio and Ribera d'Alcalà, 2009; Mayot et al., 2016; Palmiéri, 2014). The consensus regions delineated here integrate regionalisations that include seasonal dynamics, although their exact locations could vary at the interannual scale (Mayot et al., 2016). The consensus regions are thus characterised by well defined, relatively homogeneous biogeochemical and hydrodynamical conditions, with similar temporal dynamics.

For instance, the well-identified Ligurian Sea is one of the deep convection areas of the Mediterranean Sea where dense water can form (Figure 1, The Mermex Group, 2011). It is also the most productive area in the Mediterranean Sea (Morel and André, 1991; Antoine et al., 1995; Bosc et al., 2004; SiokouFrangou et al., 2010; Uitz et al., 2012), where the mean annual surface chlorophyll concentration and primary production reach more than $0.30 \mathrm{mgChl} . \mathrm{m}^{-3}$ and $180 \mathrm{gC} . \mathrm{m}^{-2}$, respectively (Bosc et al., 2004), with a strong seasonal phytoplankton bloom from late winter to early spring (Mayot et al., 2016). In this area, the intense deep convection events enhance the spring primary production rate (Mayot et al., 2017). Therefore, it is not surprising to identify a consensus region there, since most regionalisations of the Mediterranean Sea have taken the concentration or dynamics of chlorophyll into account. Two other consensus regions also correspond to bloom areas but are restricted to very coastal and shallow waters: the Gulf of Gabes and the Venetian shelf (Mayot et al., 2016). Although coastal bloom evidenced by satellite ocean color could be an artifact due to the optical properties of shallow waters enriched in diverse particulate matter, these two regions are characterised by phytoplankton blooms induced by high nutrient concentrations due to terrestrial inputs, respectively from industrial waste (Bel Hassen et al., 2009) and Po river outflow (Spillman et al., 2007; Cozzi and Giani, 2011). Surface chlorophyll

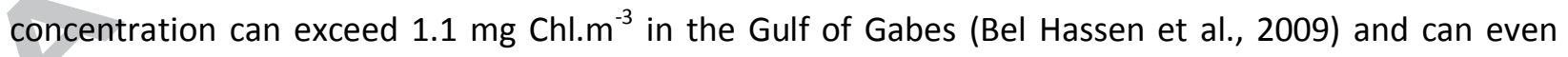

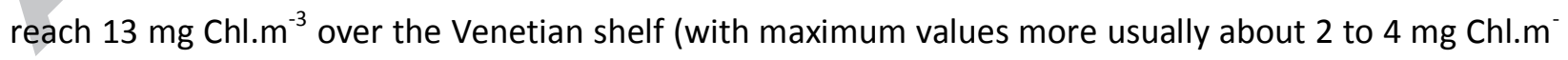

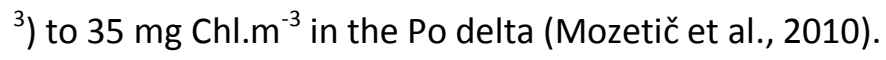


Some consensus regions are linked to strong dynamical features, even though those may not be permanent. In the deep Antalya Basin (2000-3000 m), a long-lived mesoscale anticyclonic eddy stands in the mean cyclonic flow and promotes specific hydrological and biogeochemical characteristics, such as cold water patches (Özsoy et al., 1993).

Most other consensus regions correspond to sub-basin seas (Adriatic Sea, northern Ionian Sea, southern Ionian Sea, Cretan Sea) or parts of sub-basin seas (eastern Algerian Sea, eastern Levantine Sea). They mainly reflect the counterclockwise circulation of surface waters, which forms a large ocean gyre (Figure 1; Millot and Taupier-Lepage, 2005) with relatively homogeneous biogeochemical conditions (The Mermex Group, 2011). For instance, the Cretan Sea is a region of dense water formation, characterised by a counterclockwise gyre, permanent, transitional, or recurrent eddies (Theocharis et al., 1999), and a very low nitrate concentration at the surface (Pasqueron de Fommervault et al., 2015). Indeed, in the Cretan Sea, nutrient concentrations are extremely low with values ranging from 0 or undetectable to $2.73 \mathrm{mmolN} . \mathrm{m}^{-3}$ for nitrate, $0.64 \mathrm{mmolN} . \mathrm{m}^{-3}$ for ammonium, $0.13 \mathrm{mmolP} . \mathrm{m}^{-3}$ for phosphate, and 3.74 mmolSi. $\mathrm{m}^{-3}$ for silica over the Cretan slope (Psarra et al., 2000). Due to the eastward gradient of oligotrophy in the Mediterranean Sea, the consensus regions are also characterized by different levels of surface chlorophyll and primary production. The eastern Algerian Sea and the Adriatic Sea have similar intermediate values of mean annual surface chlorophyll concentration and primary production (about $0.15 \mathrm{mg} \mathrm{Chl.m}{ }^{-3}$ and $140 \mathrm{gC} . \mathrm{m}^{-2}$ ) (Bosc et al., 2004), whereas the northern Ionian Sea, the southern Ionian Sea, and the Cretan Sea have lower values of mean annual surface chlorophyll concentration and primary production (less than $0.10 \mathrm{mg} \mathrm{Chl} . \mathrm{m}^{-3}$ and $120 \mathrm{gC} . \mathrm{m}^{-2}$ ). Finally, the eastern Levantine Sea is one

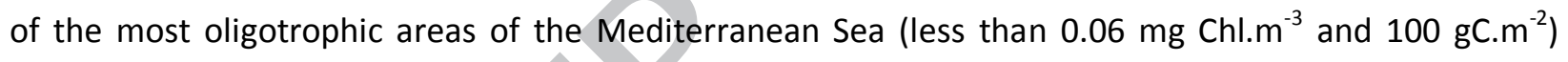
(Bosc et al., 2004). These differences propagate to the higher trophic levels (Siokou-Frangou et al., 2010), with a latitudinal gradient in zooplankton abundance (Nowaczyk et al., 2011), and differences in communities structures (Nowaczyk et al., 2011, Mazzocchi et al., 2014). For instance, in the surface waters of the Cretan Sea, appendicularian can represent $12 \%$ of the zooplankton biomass (SiokouFrangou et al., 2013), although copepods dominate the zooplankton biomass as in other areas of the Mediterranean Sea (Siokou-Frangou et al., 2010). Finally, the northern Aegean Sea is characterized by sporadic and strong meteorological events, the inflow of low temperature and low salinity water from the Black Sea, the river outflows from the Greek and Turkish mainland, the geographical distribution of the Aegean island chains, and the irregular bottom topography throughout the region (Poulos et al., 1997; Tsiaras et al., 2014). These two latter features also lead to small oceanic surfaces interspersed by many coastlines and islands, which can induce a low reliability of ocean model and of satellite data (which are the data sources of most of the regionalisations used here). Although similar nutrient concentrations have been recorded in the northern and southern Aegean Sea, a latitudinal gradient of plankton biomass and production has been described with higher values in the northern Aegean Sea (Ignatiades et al., 2002; Siokou-Frangou et al., 2002), possibly linked with temperature variability and seasonal upwelling (Poulos et al., 1997). Especially, the northern Aegean Sea has higher biomass of small phytoplankton (from 0.2 to $3.0 \mu \mathrm{m}$ ) and mesozooplankton and the microbial food web plays a key role 
in channeling carbon towards copepods in this area (Siokou-Frangou et al., 2002). In the northern Aegean Sea, spring conditions are also characterized by a relatively shallow subsurface chlorophyll maximum at about 20 to $30 \mathrm{~m}$ depth (Ignatiades et al., 2002).

\subsection{Heterogeneous regions}

A few remaining areas are characterised by many weak frontiers, indicating that, depending on which variables are considered, the regionalisations do not delineate at the exact same locations (Figure 3). These areas of scattered frontiers are found within the Alboran Sea, the Tyrrhenian Sea, the western Algerian Sea, and the western Levantine Sea. Contrary to the consensus regions, these regions are less homogeneous spatially and correspond to gradients of hydrological and biogeochemical conditions associated with a highly dynamical hydrography (d'Ovidio et al., 2004).

In the Alboran Sea, Atlantic waters entering the Mediterranean form a quasi-permanent clockwise gyre in the west and a more variable circuit in the east depending on wind conditions (Heburn and La Violette, 1990; Viudez and Tintoré, 1995), resulting in high mesoscale activities (Nieblas et al., 2014; Muñoz et al., 2015) that could explain the scattering of frontiers there. Surface waters are also colder and less salty than in the rest of the basin (The Mermex Group, 2011) and relatively more productive, especially along the Spanish coasts (Bosc et al., 2004; Uitz et al., 2012), with shallower nutriclines and deep chlorophyll maxima (Lohrenz et al., 1988). Due to its hydrological and hydrological characteristics,

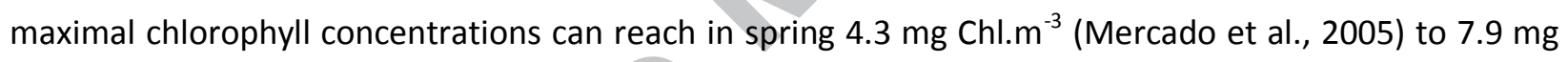
Chl.m ${ }^{-3}$ (Arin et al., 2002), with diatoms dominating the phytoplankton communities, followed by dinoflagellates and coccolitophorids (Videau et al., 1994; Claustre et al., 1994; Mercado et al., 2005) and high copepod biomass and abundances, with some species that are indicators of Atlantic waters (Thibault et al., 1994; Seguin et al., 1994; Youssara \& Gaudry, 2001).

The Tyrrhenian Sea is highly dynamical (Vetrano et al., 2010) with complex circulation patterns, including semi-permanent and transient hydrodynamical structures in the south and a pair of counterclockwise and clockwise gyres in the north (Marullo et al., 1994; Millot, 1999; Rinaldi et al., 2010). These complex and highly variable hydrodynamical features may explain why the Tyrrhenian Sea was not identified as a homogeneous region but as a heterogenous region of scattered frontiers, where various biogeochemical conditions can be observed (e.g., moderate bloom and no-bloom conditions; D'Ortenzio and Ribera d'Alcalà, 2009; Mayot et al., 2016). High proportions of cyanobacteria and dinoflagellates have been reported in the phytoplankton communities of the Tyrrhenian Sea (Decembrini et al., 2009). 
The Algerian Sea is the most energetic area regarding mesoscale activity in the entire Mediterranean Sea (Millot, 1999; Nieblas et al., 2014), with intense mesoscale eddies interacting with the unstable Algerian Current, known for its meanders (Millot, 1999; d'Ovidio et al., 2009). The western part is indeed a region of scattered frontiers but, quite surprisingly, the eastern Algerian Sea stands out as a consensus region. This may be related to the large Algerian Eddies (whose diameter can reach $200 \mathrm{~km}$ ) that are formed in this area and have a long lifetime ranging from several months up to several years (Millot et al., 1990; Puillat et al., 2002).

In the Levantine basin, the mean counterclockwise gyre circulation along the continental slope is strongly affected by numerous mesoscale eddies interconnected by jets (Özsoy et al., 1993; Hamad et al., 2006; Mkhinini et al., 2014). These clockwise eddies are created by current instability (Libyo-Egyptian eddies in the south), wind conditions (Pelops and lerapetra eddies induced by orographic effects in the north, i.e., offshore the Peloponnese and eastern Crete coasts), or by interaction with the bathymetry (Eratosthenes Seamount Eddy and Latakia Eddy, located south and east of Cyprus, respectively). The Levantine Sea is the warmest, saltiest, and most oligotrophic zone of the Mediterranean Sea (Bosc et al., 2004; Siokou-Frangou et al., 2010; The Mermex Group, 2011; Uitz et al., 2012). In the present study, the eastern Levantine Sea appears as a consensus region, but not the western and central parts, where eddies are more energetic (Gerin et al., 2006) hence resulting in higher eddy kinetic energy, considered by Nieblas et al. (2014). For example, the cyclonic Rhodes Gyres area appears as a heterogeneous region. Nonetheless, this region is well known as a formation area of the Levantine Intermediate Water (Figure 1; The Mermex Group, 2011), where the cyclonic circulation can enhance the phytoplankton production and drive occasional phytoplankton blooms (D'Ortenzio et al., 2003; Volpe et al., 2012; Siokou-Frangou et al., 2010). However, this physical-biological relationship is not clear since it is restricted to a relative small area and exhibits a very high interannual variability (Mayot et al., 2016). Therefore, such physical and biological patterns are difficult to detect by all regionalisations of the Mediterranean Sea used here and might explain why this region appears as heterogeneous.

\section{A synthetic view of the epipelagic Mediterranean Sea}

From the review and comparison of the recent regionalisations of the Mediterranean Sea, this study proposes the first regionalisation based on the consensus of several regionalization studies of the epipelagic open seas in the Mediterranean basin. Because it is based on multiple and independent approaches, this new regionalisation should provide a more synthetic and consensual view of the structure of the Mediterranean Sea than any dedicated study. Using the congruence of frontiers among regionalisations, we were able to identify consensus frontiers, consensus homogeneous regions, and heterogeneous regions.

\subsection{Consensual biogeography of the Mediterranean Sea}


In the present synthesis, rather than dividing the entire Mediterranean Sea into contiguous ecoregions (as in previous regionalisation studies), we identified a few consensus regions and frontiers, which result from the agreement of diverse regionalisations and are related to congruent and coherent hydrodynamical, biogeochemical, and ecological features. The consensus regions proposed here could then be seen as the (relatively) homogenous cores of larger ecoregions, whose boundaries can be loose and/or related to consensus frontiers. Areas characterized by scattered frontier congruence indicate dynamical regions, in which the location of fronts between water masses vary with time, from mesoscale to seasonal scale. Although previous regionalisations may be more suited to address specific questions (for instance focusing on current-driven regionalisation for genetic and dispersal studies, on niche based regionalisation for diversity studies, or on environmental based regionalisation for biogeochemical studies, etc.), the consensus proposed here gives a synthetic, unified and global regionalisation of the Mediterranean Sea, that could be seen as a general agreement of different approaches. As any consensus, it does not necessarily conform to all the constraints from each previous regionalisation (and may not be adapted to specific questions), but it proposes a general agreement, as needed for multidisciplinary studies or managerial/political actions.

The congruence between regionalisations based solely on hydrodynamics (i.e., Berline et al., 2014; Rossi et al., 2014) and solely on biogeochemical variables (i.e., Mayot et al., 2016; Palmiéri, 2014; Reygondeau et al., 2014; Reygondeau et al., 2017) suggests that the horizontal circulation explains a significant part of the distribution of hydrological and ecological variables at basin scale. Indeed, the frontiers and regions identified are often associated with large scale hydrodynamical features of the basin, which induce homogeneous hydrological and biogeochemical conditions within regions and sharp gradients at their boundaries (Nieblas et al., 2014). But we also show that basin-level gyres do not always define consensus regions: when mesoscale activity is intense, the mixing of water masses creates locally highly variable conditions and gradients which induce a scattering of regionalisation frontiers (e.g., Tyrrhenian Sea). Finally, the robust frontiers that this approach highlights are likely as significant for marine ecosystems as the consensus regions that regionalisation studies usually focus on. For example, many consensus frontiers coincide with frontal structures that may favour primary production (Franks, 1992; Claustre et al., 1994; Videau et al., 1994, for the Almeria-Oran front).

Since regions need to coincide among various regionalisations to be considered consensual, the consensus regions defined here are necessarily smaller than the ones identified previously. However, it highlights the fact that the ocean cannot be simply represented as large regions with homogeneous environmental conditions separated by sharp frontiers. The location of these frontiers is an artefact of the necessary but somewhat arbitrary choices regarding the variables considered, the clustering algorithm, and the cutoff level in each study. By combining studies, these choices are averaged and the consensus accurately depicts that some areas simply cannot be classified. This was already recognised by several underlying studies, which used various clustering configurations and computed maps of the 
frequency of frontiers (e.g., Reygondeau et al., 2017; Rossi et al., 2014) but then used those to define synthetic and contiguous regions, because this is the expected output of a regionalisation study.

\subsection{Implications for future biogeochemical and ecological studies}

The fact that true consensus regions are smaller than previously found could have direct impacts on our ability to understand marine ecosystems. For instance, if one was to characterise the dynamics of key biogeochemical variables or pelagic species in some parts of the Mediterranean Sea, a cruise or a time series would not have the same representativeness if it was conducted within a consensus region or outside. Many basin-scale cruises have sampled the Mediterranean waters along a North-West to SouthEast transect (e.g., Pujo-Pay et al., 2011, and Moutin et al, 2012, for biogeochemical variables; Ignatiades et al., 2009, for phytoplankton; Nowaczyk et al., 2011, and Mazzocchi et al., 2014, for zooplankton) following the latitudinal gradient of oligotrophy (Bosc et al., 2004). However, it appears from our study that such a transect may not cross consensus regions but rather, may sample highly dynamical consensus frontiers. Therefore, the extrapolation to the entire basin of such observations along an oligotrophic gradient may be hampered. More interestingly, this points out that the longitudinal oligotrophic gradient may not cross regions characterized by consensus gradients in hydrodynamical, biogeochemical, and ecological features. On the contrary, a few studies have sampled along two longitudinal transects, one northern, one southern, and may have captured more representative features by crossing consensus regions (e.g., Dolan et al., 2002). We suggest that our regionalisation could be used to optimize the sampling strategy of future biogeochemical and ecological studies by targeting different consensus regions within the Mediterranean Sea. We also argue that more effort should be given to the description of the consensus regions and frontiers, rather than to other more variable and heterogeneous areas, and to the confirmation that a measure within a consensus region could be considered representative of a wider region (for instance using autonomous plateforms as BGC-Argo floats or gliders). Such a regionalisation-based approach was proposed by the NAOS-Med Team (2012) for the deployments of BGC-Argo floats in the Mediterranean Sea, based on the regionalisation of D'Ortenzio and Ribera d'Alcalà (2009). Optimizing the sampling strategy of future genetic studies by targeting different consensus regions could also help formulating and testing hypotheses pertaining to the role of larval dispersal in the spatial and genetic structuring of marine populations (Dubois et al., 2016). Our results may also help in designing optimal observation networks and raise the question of the representativeness of offshore Mediterranean time series that may not be located within consensus regions. Consensus regions could be used as target areas for the deployment of observing systems, since they could be used as indicators of the spatial extent of the region that is effectively monitored (Oke and Sakov, 2012). Therefore, in order to document conditions that are relatively homogeneous and long-lasting, floats and observatory should rather be deployed within consensus regions. On the contrary, if they were to track more dynamical features, floats and observing system should be deployed within consensus frontiers or within heterogeneous regions. Thus, the consensus frontiers and regions proposed in this study can help the planning of scientific cruises, the 
release and data interpretation of floats such as ARGO and BGC-Argo (e.g., Poulain et al., 2007) and, as suggested by The Mermex Group (2011), can help the design and the deployment of an optimal large scale observatory such as MOOSE (Mediterranean Ocean Observing System for the Environment, http://www.moose-network.fr/), as well as the choice of Fixed-Point Open Ocean Observatories (FixO3, http://www.fixo3.eu/).

\subsection{Implications for management and conservation planning}

The vision of the Mediterranean Sea as a mosaic of more or less homogeneous regions separated by robust frontiers also has consequences for ecosystem management and spatial planning. So far, the Marine Ecoregions of the World (MEOW) proposed by Spalding et al. (2007), and reused by Halpern et al. (2008) to depict human impacts on marine ecosystems, have set the geographical context for biodiversity studies and associated threats in the Mediterranean Sea (Coll et al., 2012; Micheli et al., 2013a). The seven Mediterranean ecoregions of Spalding et al. (2007) displayed comparable levels of cumulative human impacts, although the underlying drivers differed between regions (Micheli et al., 2013a). Cumulative human impacts were also comparable among our consensus regions (Figure 5a), with average impacts per region ranging from 6.5 to 9.1 while the full scale in Micheli et al. (2013a) is 1.5 to 19.1. Yet, the more offshore and western regions (e.g., Ligurian) had lower impacts than the more inshore and eastern regions (e.g., Antalyan). Indeed, human activities are concentrated close to the coasts and climate change is projected to be stronger in the eastern basin (Micheli et al., 2013a; Adloff et al., 2015).

The areas of high human impacts are often associated with intense fishing that occurs in dynamical and productive regions, close to the shore. With such characteristics, those areas are mostly excluded from the homogeneous consensus regions defined here. Fortunately, these impacted areas are also the ones targeted by current and future marine management plans (Figure 5b; Micheli et al., 2013b; Piante and Ody, 2015). Yet, the only pelagic Marine Protected Area (MPA) of the Mediterranean Sea, the Pelagos Sanctuary for marine mammals that spans $>87,500 \mathrm{~km}^{2}$ around Corsica and between France, Italy, and Sardinia (Notarbartolo di Sciara et al., 2008), encompasses only part of the Ligurian region as well as the Corsica-Italy consensus frontier. Similarly, only the central Adriatic Sea is proposed for conservation while our study shows that the southern part functions in a similar fashion. The same is true for a small portion of the Levantine consensus region. This raises the question of whether the protection of such diverse pelagic habitats was an explicit goal when creating or proposing these MPAs or a byproduct of other choices. In the Alboran Sea, an MPA has been proposed and its eastern limits are congruent with a consensus frontier. In general, the areas proposed for conservation in the Mediterranean Sea are mainly located in coastal areas. As a consequence, the consensus regions that cover mainly offshore water (ie., the Eastern Algerian Sea, the Northern Ionian Sea, and the Southern Ionian Sea) are not included in potential conservation planning. For the efficacy of the conservation effort when delineating pelagic MPAs, to consider ocean dynamics is important (Grantham et al., 2011; Dubois et al., 2016), as well as 
biogeochemical properties (such as productive areas), or the inclusion of the different facets of biodiversity (e.g., Mouillot et al., 2011). Management plans have multiple objectives and a consensus regionalisation can help in addressing them simultaneously. Our consensus regionalisation could then be used for designing MPAs that would cover productive environments (reflecting high nutrients supply, high biomass, and good habitat quality) with coherent dispersion patterns (hence including currentdriven regionalisation) and finally "pristine locations" where cumulative impacts are relatively low (Figure 5a).
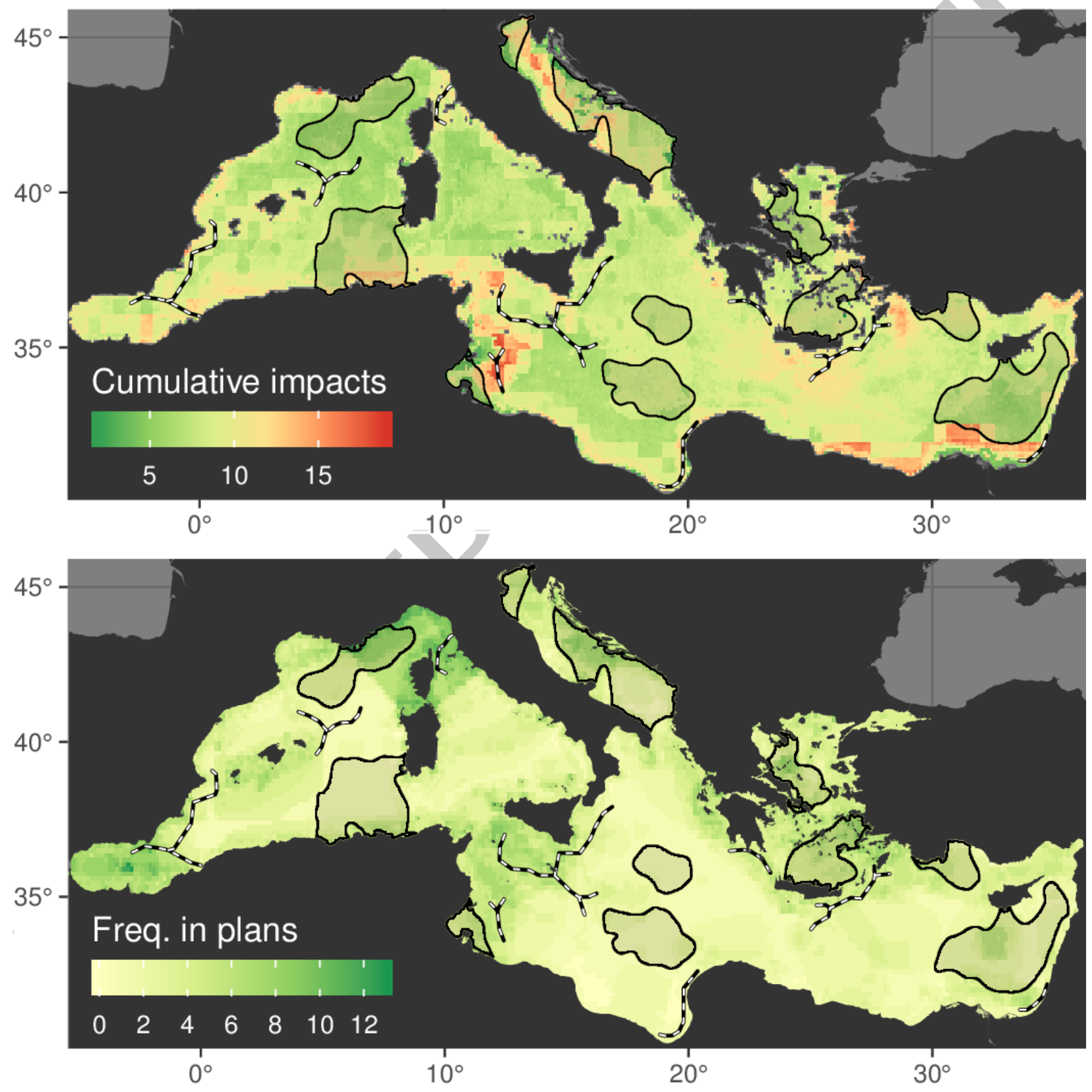

Figure 5: Consensus regions and frontiers overlaid on a) the cumulative human impacts on the Mediterranean Sea, from Micheli et al. (2013a) and b) the frequency of inclusion in spatial conservation plans, from Micheli et al. (2013b). Map (a) cumulates 22 anthropogenic drivers, whether direct (e.g., 
fisheries, shipping, coastal population density) or indirect (e.g., acidification, sea surface warming, hypoxia). Map (b) considers six existing and twelve proposed conservation plans in the Mediterranean Sea (data kindly provided by the authors).

Regionalisation has a different meaning for stakeholders (i.e., regional cooperation on conservation measures) and for scientists (i.e., identification of regions with homogeneous abiotic and biotic conditions). The present synthesis should help to identify coherent regions for ecosystem-based management by providing objective spatial information on ocean and ecosystem dynamics (Pınarbaşı et al., 2017). An ecosystem approach to management requires the monitoring of a wide range of ecosystem components (from nutrients and plankton to fish and top predators) and processes (biogeochemical fluxes and trophic dynamics) in a cost-effective way (Borja and al., 2016; Kupschus et al., 2016). Ecosystem-based approaches should then be adopted at a spatial scale driven by the spatial heterogeneity of ecosystem processes. The consensus regions identified in the present study could be good candidates for targeted monitoring programs and conservation planning. In Europe, the Marine Strategy Framework Directive (MSFD) requires such regionalisation for the definition of indicators of Good Environmental Status (GES), particularly for the pelagic habitat indicators but also for some foodwebs ones (Elliot et al., 2017). For instance in the North-East Atlantic, the regionalisation of Van Leeuwen et al. (2015) in the North Sea, based on stratification regimes of the water column, has been used for the evaluation of some of these indicators in the frame of the OSPAR convention (Convention for the Protection of the Marine Environment of the North-East Atlantic, named after Oslo and Paris Conventions). However, it does not cover the whole OSPAR area resulting in heterogeneous evaluation of indicators (cf. OSPAR 2017 Intermediate assessment, available at www.ospar.org). Using large-scale consensus regionalisation approach has the following advantages: use of homogeneous indicator assessment within member states, which increases the chance of acceptance by funding institutions, shorter-term political decision processes in the existence of common member-states scientific reliable tools, and feasibility of cost-effective monitoring and management programs through member-states cooperation using the same indicators at the same scale. In the Mediterranean Sea, the development of regional indicators is at his premises through the Barcelona Convention (Convention for the Protection of the Marine Environment and the Coastal Region of the Mediterranean), but the consensus regionalisation proposed here could be the basis for developing common indicators, since they correspond to geographical entities with relatively coherent features, particularly for indicators dedicated to pelagic habitats which need to be considered in any ecosystemic approach to management (McQuatters-Gollop et al., 2017). Besides, such a regionalisation study can be of particular importance in the absence of consensus at the geopolitical level, such as for the Mediterranean where most countries have not declared Exclusive Economic Zones (EEZ) (Chevalier, 2005) and are not under a current common policy framework such as the MSFD. In addition to the scientific reliability of such approach, the large-scale homogenous method allows the existence of an objective tool that can significantly increase the speed of working groups' decision processes. For all these reasons, we recommend the 
consideration of the present regionalisation of the Mediterranean Sea at the political and management levels.

There are however some limits to its application. Since we focused on the epipelagic layer of the Mediterranean Sea, the consensus regions are not adapted for fisheries management, for which the General Fisheries Council for the Mediterranean (GFCM, http://www.gfcm.org/) has already proposed 27 geographical subareas (essentially based on political criteria) for estimating fish stocks in the Mediterranean Sea. Besides, fish such as bluefin tuna are known for their migrations over large spatial scales within the Mediterranean Sea and across the Atlantic (Block et al, 2005; Fromentin and Lopuszanski, 2014; Cermeño et al., 2015).

\subsection{Future work}

This synthesis opens several perspectives for the regionalisation of the Mediterranean Sea. Human impacts over the whole basin, such as the ones documented in Micheli et al. (2013a), could be used to compute a statistical regionalisation dedicated to human activities. This would allow the identification of regions under similar pressures. Other zonations of human activities in the Mediterranean Sea are documented in the MedTrends Project of WWF (http://medtrends.org/; Piante and Ody, 2015), such as conserved versus open areas, regions of prospection for oil and gas, etc. It would then be interesting to estimate the congruence of such regions with the present work, based solely on abiotic and biotic variables.

The availability of several regionalisation studies and their relative agreement, described here, may give the impression that our knowledge of the functioning of the Mediterranean Sea is now stable and complete. Yet, maps of the density of data points for classic hydrological and biogeochemical variables highlight substantial gaps, as can be shown for the data used to compute climatologies in the World Ocean Atlas (WOA; Figure 6). Other regional databases may hold more complete but spatio-temporally restricted cast records; e.g. MISTRALS in France http://mistrals.sedoo.fr, containing the MEDAR/MEDATLAS dataset http://mistrals.sedoo.fr/?editDatsld=677\&datsld=677; IBAMar in Spain http://www.ba.ieo.es/ibamar). But WOA is one of the most extensive sources of gridded oceanographic products and is therefore used by many biogeography studies. Even for temperature (the best informed variable thanks to the extensive use of bathythermographs) data is still lacking over the Tunisian Plateau and the Gulf of Sidra, with fewer than 10 data points per $0.25^{\circ}$ square over the last 60 years, and more generally offshore the southern coasts of the eastern Mediterranean Basin. All other variables display the same pattern but are even less informed overall; only the northern parts have been extensively sampled. Although geopolitical concerns may explain the lack of data off Libya, this is not true for the Tunisian Plateau and most of the poorly sampled offshore regions. A strong effort should now be put on collecting existing data, collecting new biogeochemical data in the open waters of the Mediterranean Sea and making it available in open online databases. 


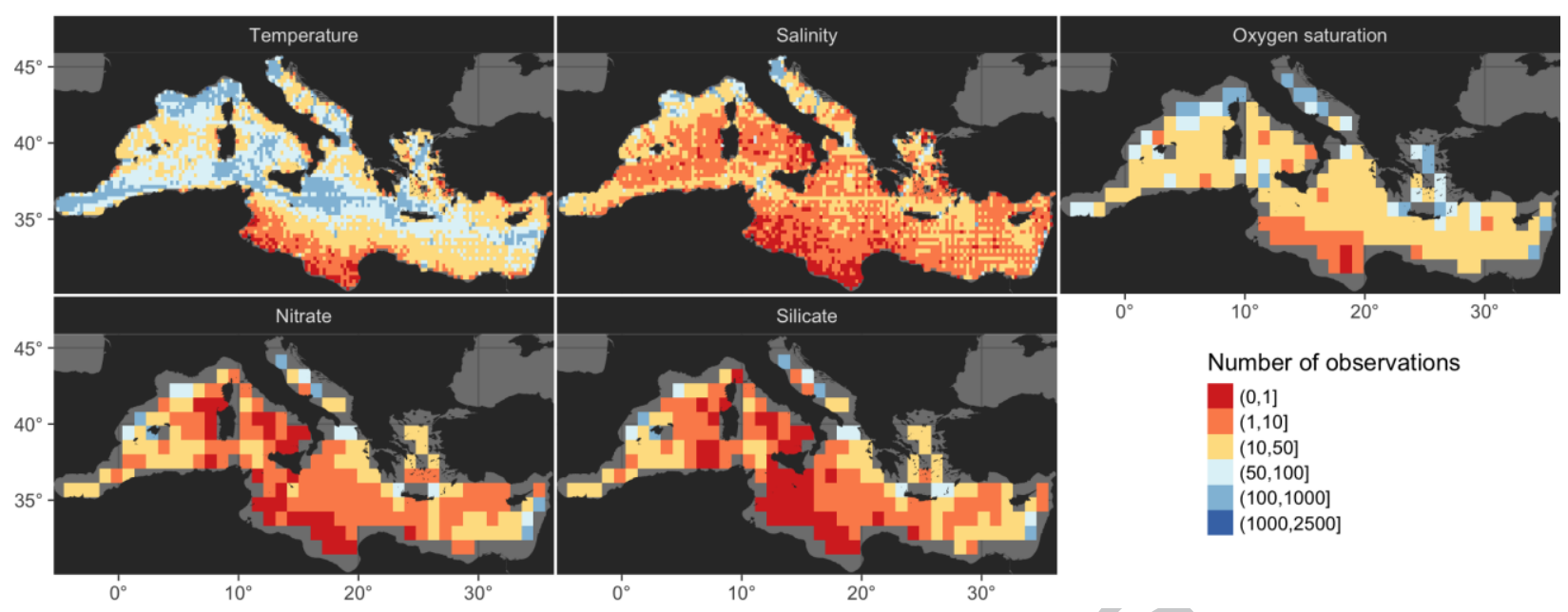

Figure 6: Average number of observations used to compute the climatologies of classic hydrological and biogeochemical variables between 0 and $100 \mathrm{~m}$ in the World Ocean Atlas (WOA; since 1955, downloaded from http://data.nodc.noaa.gov/thredds/dodsC/woa/WOA13/DATAv2/). NB: the colour scale is not linear, otherwise the map would be dominated by a few pixels with very dense data which are not representative of the overall sampling effort in the basin.

Finally, the current context of climate change raises the question of how the synthetic view presented here could be altered in the future. Indeed, by the end of the century, the general circulation could reach a situation similar to the present-day Eastern Mediterranean Transient (EMT), because of the warming and increased salinity expected for the entire Mediterranean Basin (Adloff et al., 2015). The EMT is a modification of the circulation whereby deep water formation zones shift from the Adriatic Sea to the Aegean Sea (Roether et al., 2007). This shift has major implications for the hydrologic characteristics of the intermediate and deep waters of the eastern Mediterranean Basin (Cardin et al., 2015). Given how strongly the general circulation shapes the consensus regions outlined above, such a shift would likely change this consensus map and the long term management plans for pelagic areas would need to account for it. A regionalisation based on the outputs of several coupled biogeochemical ocean models at the regional scale $s$ forced by climatic scenarios would help in estimating how climate change, and the associated alterations of hydrodynamic and hydrologic patterns, could modify the epipelagic ecosystems of the Mediterranean Sea in the near future.

Like the four other Semi Enclosed Seas (SES) (Black Sea, Baltic Sea, Arabian Gulf, Red Sea), the Mediterranean Sea is highly vulnerable to both local and global stressors due to its small volume and disconnected nature (compared to other oceanic environments). Consequently Mediterranean Sea and other SES will respond faster than most other parts of the Ocean to changes in global temperature (Hoegh-Guldberg et al., 2014). There is thus a strong interest that solid regionalisation of those particular oceanic environments are made both taking into account the current state of knowledge and the future conditions. 


\section{Acknowledgments}

This study was conducted as part of the WP5 MERMEX/MISTRALS project and is a contribution to the international SOLAS, IMBER and LOICZ programs. The lead authors are grateful to Pr. Philippe Koubbi (MNHN) for initiating (eco)regionalisation studies of the Mediterranean Sea at the Laboratoire d'Océanographie de Villefranche sur mer (LOV, UPMC/CNRS). Some initial thoughts that have led to this synthesis were also supported by the PlankMed action of WP5 MERMEX and by the EC FP7 PERSEUS Project (Policy-oriented marine Environmental Research in the Southern EUropean Seas; Grant. Agr. 287600). The authors are grateful to F. Micheli and N. Levin for openly sharing their data regarding the cumulative impacts and conservation schemes in the Mediterranean Sea and to two anonymous reviewers for their constructive comments.

\section{Bibliography}

Adloff, F., Somot, S., Sevault, F., Jordà, G., Aznar, R., Déqué, M., Herrmann, M., Marcos, M., Dubois, C., Padorno, E., AlvarezFanjul, E., Gomis, D., 2015. Mediterranean Sea response to climate change in an ensemble of twenty first century scenarios. Climate Dynamics 45, 2775-2802.

Antoine, D., Morel, A., André, J.M., 1995. Algal pigment distribution and primary production in the eastern Mediterranean as derived from coastal zone color scanner observations, Journal of Geophysical Research Ocean., 100(C8), 16193 16209.

Arin, L., Moràn, X.A.G., Estrada, M., 2002. Phytoplankton size distribution and growth rates in the Alboran Sea (SW Mediterranean): short term variability related to mesoscale hydrodynamics. Journal of Plankton Research, 24, 10191033.

Bel Hassen, M., Hamza, A., Drira, Z., Zouari, A., Akrout, F., Messaoudi, S., Aleya, L., Ayadi, H., 2009. Phytoplankton-pigment signatures and their relationship to spring-summer stratification in the Gulf of Gabes. Estuarine, Coastal and Shelf Science 83, 296-306.

Berline, L., Rammou, A., Doglioli, A., Molcard, A., Petrenko, A., 2014. A connectivity-based ecoregionalization of the mediterranean sea. Plos One 9(11) e111978. doi: 10.1371/journal.pone.0111978.

Bethoux, J., Gentili, B., Morin, P., Nicolas, E., Pierre, C., Ruiz-Pino, D., 1999. The Mediterranean Sea: a miniature ocean for climatic and environmental studies and a key for the climatic functioning of the North Atlantic. Progress in Oceanography 44, 131-146.

Bianchi, C., Morri, C., 2000. Marine biodiversity of the mediterranean sea: Situation, problems and prospects for future research. Marine Pollution Bulletin 40, 367-376.

Block, B. A., Teo, S.L.H., Walli, A., Boustany, A., Stokesbury, M.J.W., Farwell, C.J., Weng, K.C., Dewar, H., Williams, T.D., 2005. Electronic tagging and population structure of Atlantic bluefin tuna. Nature, 434, 1121-1127.

Borja A., Elliott M., Snelgrove P. V., Austen M. C., Berg T., Cochrane S., Carstensen J., Danovaro R., Greenstreet S., Heiskanen AS., Lynam C. P., Mea M., Newton A., Patrício J., Uusitalo L., Uyarra M. C., Wilson C. (2016). Bridging the gap between policy and science in assessing the health status of marine ecosystems. Frontiers in Marine Science, 3, 175.

Bosc, E., Bricaud, A., Antoine, D., 2004. Seasonal and interannual variability in algal biomass and primary production in the mediterranean sea, as derived from 4 years of seawifs observations. Global Biogeochemical Cycles 18. GB1005.

Cardin, V., Civitarese, G., Hainbucher, D., Bensi, M., Rubino, A., 2015. Thermohaline properties in the Eastern Mediterranean in the last three decades: is the basin returning to the pre-EMT situation? Ocean Science11, 53-66. 
Cermeño, P., Quílez-Badia, G., Ospina-Alvarez, A., Sainz-Trápaga, S., Boustany, A.M., Seitz, A.C., Tudela, S., Block, B.A., 2015. Electronic Tagging of Atlantic Bluefin Tuna (Thunnus thynnus, L.) Reveals Habitat Use and Behaviors in the Mediterranean Sea. PLOS ONE 10(2): e0116638

Chevalier, C., 2005. Governance of the Mediterranean Sea. Outlook for the Legal Regime. Technical Report. IUCN-Med, Málaga (Spain).

Claustre, H., Kerhervé, P., Marty, J.C., Prieur, L., Videau, C., Hecq, J.H., 1994. Phytoplankton dynamics associated with a geostrophic front: Ecological and biogeochemical implications. Journal of Marine Research 52 (4), 711-742.

Coll, M., Piroddi, C., Albouy, C., Lasram, F.B.R., Cheung, W.W.L., Christensen, V., Karpouzi, V.S., Guilhaumon, F., Mouillot, D., Paleczny, M., Palomares, M.L., Steenbeek, J., Trujillo, P., Watson, R., Pauly, D., 2012. The mediterranean sea under siege: spatial overlap between marine biodiversity, cumulative threats and marine reserves. Global Ecology and Biogeography 21, 465-480.

Coll, M., Piroddi, C., Steenbeek, J., Kaschner, K., Lasram, F.B.R., Aguzzi, J., Ballesteros, E., Bianchi, C.N., Corbera, J., Dailianis, T., Danovaro, R., Estrada, M., Froglia, C., Galil, B.S., Gasol, J.M., Gertwagen, R., Gil, J., Guilhaumon, F., Kesner-Reyes, K., Kitsos, M.S., Koukouras, A., Lampadariou, N., Laxamana, E., Lopez-Fe de la Cuadra, C.M., Lotze, H.K., Martin, D., Mouillot, D., Oro, D., Raicevich, S., Rius-Barile, J., Ignacio Saiz-Salinas, J., San Vicente, C., Somot, S., Templado, J., Turon, X., Vafidis, D., Villanueva, R., Voultsiadou, E., 2010. The Biodiversity of the Mediterranean Sea: Estimates, Patterns, and Threats. Plos One 5(8), e11842. doi:10.1371/journal.pone.0011842.

Commonwealth of Australia, 2006. A Guide to the Integrated Marine and Coastal Regionalisation of Australia Version 4.0. Technical Report. Department of the Environment and Heritage, Canberra, Australia.

Costello, M., 2009. Distinguishing marine habitat classification concepts for ecological management. Marine Ecology Progress Series 397, 253-268.

Cozzi, S., Giani, M., 2011. River water and nutrient discharges in the Northern Adriatic Sea: Current importance and long term changes. Continental Shelf Research 31, 1881-1893.

Davies, P., Folkard, A., Chabert d'Hières, G., 1993. Remote sensing observations of filament formation along the almeria-oran front. Annales Geophysicae 11, 419-430.

Decembrini, F., Caroppo, C., Azzaro, M., 2009. Size structure and production of phytoplankton community and carbon pathways channelling in the Southern Tyrrhenian Sea (Western Mediterranean), Deep-Sea Research Part II, 56, 687-699

Delavenne, J., Marchal, P., Vaz, S., 2013. Defining a pelagic typology of the eastern english channel. Continental Shelf Research 52, 87-96.

Dolan, J., Claustre, H., Carlotti, F., Plounevez, S., Moutin, T., 2002. Microzooplankton diversity: relationships of tintinnid ciliates with resources, competitors and predators from the Atlantic Coast of Morocco to the Eastern Mediterranean. Deep Sea Research Part I: Oceanographic Research Papers 49, 1217-1232.

D’Ortenzio, F., Ragni, M., Marullo, S., Ribera d'Alcalà, M., 2003. Did biological activity in the lonian Sea change after the Eastern Mediterranean Transient? Results from the analysis of remote sensing observations. Journal of Geophysical Research Oceans, 108, 14-20.

D’Ortenzio, F., ludicone, D., de Boyer Montegut, C., Testor, P., Antoine, D., Marullo, S., Santoleri, R., Madec, G., 2005. Seasonal variability of the mixed layer depth in the mediterranean sea as derived from in situ profiles. Geophysical Research Letters 32. L12605. doi:10.1029/2005GL022463.

D'Ortenzio, F., Ribera d'Alcalà, M., 2009. On the trophic regimes of the Mediterranean Sea: a satellite analysis. Biogeosciences 6, 139-148.

D'Ovidio, F., Fernandez, V., Hernandez-Garcia, E., Lopez, C., 2004. Mixing structures in the Mediterranean Sea from finite-size Lyapunov exponents. Geophysical Research Letters 31, L17203. doi:10.1029/2004GL020328.

D'Ovidio, F., Isern-Fontanet, J., Lopez, C., Hernandez-Garcia, E., Garcia-Ladon, E., 2009. Comparison between Eulerian diagnostics and finite-size Lyapunov exponents computed from altimetry in the Algerian basin. Deep-Sea Research I $56,15-31$. 
Dubois, M., Rossi, V., Ser-Giacomi, E., Arnaud-Haond, S., López, C., Hernández-García, E., 2016. Linking basin-scale connectivity, oceanography and population dynamics for the conservation and management of marine ecosystems. Global Ecology and Biogeography 25, 503-515.

Elliot, S.A.M., Arroyo, N.L., Safi, G., Ostle, C., Guérin, L., McQuatters-Gollop, A., Aubert, A., Artigas, F., Budria, A., Rombouts, I., Pesh, R., Schmitt, P., Vina-Herbon, C., Meakins, B., Gonzales-Irusta, J.M., Preciado, I., LopezLopez, I., Puzon, A., Torriente, A., Serrano, A., Haraldsson, M., Capuzzo, E., Claquin P., Kromkamp, J., Niquil, N., Judd, A., Padegimas, B., Corcoran, E., 2017. Proposed approaches for indicator integration. Contribution to the EU Co-financed EcApRHA project (Applying an ecosystem approach to (sub) regional habitat assessments), Deliverable report 4.1., $42 p$

Franks, P.J., 1992. Phytoplankton blooms at fronts: patterns, scales, and physical forcing mechanisms. Reviews in Aquatic Sciences 6(2), 121-137.

Fromentin, J.M, Lopuszanski, D., 2014. Migration, residency, and homing of bluefin tuna in the western Mediterranean Sea. ICES Journal of Marine Sciences, 71 (3), 510-518.

Gerin, R., Poulain, P.-M., Taupier-Letage, I., Millot, C., Ben Ismail, S., Sammari, C., 2009. Surface circulation in the Eastern Mediterranean using drifters (2005-2007). Ocean Science 5, 559-574.

Grantham, H.S., Game, E.T., Lombard, A.T., Hobday, A.J., Richardson, A.J., Beckley, L.E., Pressey, R.L., Huggett, J.A., Coetzee, J.C., van der Lingen, C.D., Petersen, S.L., Merkle, D., Possingham, H.P., 2011. Accommodating dynamic oceanographic processes and pelagic biodiversity in marine conservation planning. PLOS ONE 6(2): e16552. doi:10.1371/journal.pone.0016552

Halpern, B.S., Walbridge, S., Selkoe, K.A., Kappel, C.V., Micheli, F., D’Agrosa, C., Bruno, J.F., Casey, K.S., Ebert, C., Fox, H.E., Fujita, R., Heinemann, D., Lenihan, H.S., Madin, E.M.P., Perry, M.T., Selig, E.R., Spalding, M., Steneck, R., Watson, R., 2008. A global map of human impact on marine ecosystems. Science 319, 948-952.

Hamad, N., Millot, C., Taupier-Letage, I., 2006. The surface circulation in the eastern basin of the Mediterranean Sea. Scientia Marina 70(3), 457-503.

Harrower, M., Brewer, C.A., 2003. Colorbrewer.org: An online tool for selecting colour schemes for maps. The cartographic journal 40(1), 27-37.

Hattab, T., Albouy, C., Ben Rais Lasram, F., Le Loc'h, F., Guilhaumon, F., Leprieur, F., 2015. A biogeographical regionalization of coastal mediterranean fishes. Journal of Biogeography 42, 1336-1348.

Heburn, G., La Violette, P., 1990. Variations in the structure of the anticyclonic gyres found in the alboran sea. Journal of Geophysical Research 95, 1599-1613.

Hoegh-Guldberg, O., Cai ,R., Poloczanska, E.S., Brewer, P.G., Sundby, S., Hilmi, K., Fabry, V.J., Jung, S., 2014. The Ocean. In: Climate Change 2014: Impacts, Adaptation, and Vulnerability. Part B: Regional Aspects. Contribution of Working Group II to the Fifth Assessment Report of the Intergovernmental Panel on Climate Change [Barros, V.R., C.B. Field, D.J. Dokken, M.D. Mastrandrea, K.J. Mach, T.E. Bilir, M. Chatterjee, K.L. Ebi, Y.O. Estrada, R.C. Genova, B. Girma, E.S. Kissel, A.N. Levy, S. MacCracken, P.R. Mastrandrea, L.L.White (eds.)]. Cambridge University Press, Cambridge, United Kingdom and New York, NY, USA, pp. 1655-1731.

ICES, 2005. Report of the ICES Advisory Committee on Fishery Management, Advisory Committee on the Marine Environment and Advisory Committee on Ecosystems. Volumes 1-11. 1,418 pp. Technical Report. ICES Advice.

Ignatiades, L., Psarra, S., Zervakis, V., Pagou, K., Souvermezoglou, E., Assimakopoulou, G., Gotsis-Skretas, O., 2002. Phytoplankton size-based dynamics in the Aegean Sea (Eastern Mediterranean). Journal of Marine Systems 36, 1128.

Ignatiades, L., Gotsis-Skretas, O., Pagou, K., Krasakopoulou, E., 2009. Diversification of phytoplankton community structure and related parameters along a large-scale longitudinal east-west transect of the Mediterranean Sea, Journal of Plankton Research, 31, 411-428.

Kupschus, S., Schratzberger, M., Righton, D., 2016. Practical implementation of ecosystem monitoring for the ecosystem approach to management Journal of Applied Ecology, 53, 1236-1247. 
Lavigne, H., D’Ortenzio, F., Migon, C., Claustre, H., Testor, P., d’Alcalà, M. R., Lavezza, R., Houpert, L., Prieur, L., 2013. Enhancing the comprehension of mixed layer depth control on the mediterranean phytoplankton phenology, Journal of Geophysical Research: Oceans 118, 3416-3430.

Lejeusne, C., Chevaldonné, P., Pergent-Martini, C., Boudouresque, C.F., Pérez, T., 2010. Climate change effects on a miniature ocean: the highly diverse, highly impacted mediterranean sea. Trends in Ecology \& Evolution 25, 250-260.

Lohrenz, S.E., Wiesenburg, D.A., DePalma, I.P., Johnson, K.S., Gustafson, D.E., 1988. Interrelationships among primary production, chlorophyll, and environmental conditions in frontal regions of the western mediterranean sea. Deep Sea Research Part A. Oceanographic Research Papers 35, 793-810.

Longhurst, A.R., 1998. Ecological geography of the sea. Academic Press: San Diego. ISBN 0-12-455559-4. 398 pp

López-García, M.J., Millot, C., Font, J., García-Ladona, E., 1994. Surface circulation variability in the balearic basin. Journal of Geophysical Research: Oceans 99, 3285-3296.

Macpherson, E., Raventos, N., 2006. Relationship between pelagic larval duration and geographic distribution of Mediterranean littoral fishes. Marine Ecology Progress Series 327, 257-265.

Marullo, S., Santoleri, R., Bignami, F., 1994. The Seasonal and Interannual Variability of the Western Mediterranean Sea, Coastal and Estuarine Studies 46. Chapter : The surface characteristics of the Tyrrhenian Sea: Historical satellite data analysis. p. 135-154.

Mayot, N., D’Ortenzio, F., Ribera d'Alcalà, M., Lavigne, H., Claustre, H., 2016. Interannual variability of the mediterranean trophic regimes from ocean color satellites. Biogeosciences 13, 1901-1917.

Mayot, N., D’Ortenzio, F., Uitz, J., Gentili, B.,. Ras, J., Vellucci, V., Golbol, M., Antoine, D., Claustre, H., 2017. Influence of the phytoplankton community structure on the spring and annual primary production in the North-Western Mediterranean Sea. Journal of Geophysical Research Ocean. doi:10.1002/2016JC012668

Mazzocchi, M., Siokou, I., Tirelli, V., Bandelj, V., de Puelles, M. F., Örek, Y. A., de Olazabal, A., Gubanova, A., Kress, N., Protopapa, M., Solidoro, C., Taglialatela, S. , Kurt, T. T., 2014. Regional and seasonal characteristics of epipelagic mesozooplankton in the Mediterranean Sea based on an artificial neural network analysis. Journal of Marine Systems, 135, 64-80.

McQuatters-Gollop, A., Johns, D., Bresnan, E., Skinner, J., Rombouts, I., Stern, R., Aubert, A., Johansen, M., Bedford, J., Knights, A., 2017. From microscope to management: the critical value of plankton taxonomy to marine policy and biodiversity conservation, Marine Policy, 83, 1-10.

Mercado, J. M., Ramírez, T., Cortés, T., Sebastiàn, T., and Vargas- Yàñez, M., 1994. Seasonal and inter-annual variability of the phytoplankton communities in an upwelling area of the Alborán Sea (SW Mediterranean Sea). Scientia Marina, 69, 451-465.

Micheli, F., Halpern, B.S., Walbridge, S., Ciriaco, S., Ferretti, F., Fraschetti, S., Lewison, R., Nykjaer, L., Rosenberg, A.A., 2013a. Cumulative human impacts on mediterranean and black sea marine ecosystems: Assessing current pressures and opportunities. Plos One 8(12): e79889. doi:10.1371/journal.pone.0079889.

Micheli, F., Levin, N., Giakoumi, S., Katsanevakis, S., Abdulla, A., Coll, M., Fraschetti, S., Kark, S., Koutsoubas, D., Mackelworth, P., Maiorano, L., Possingham, H.P., 2013b. Setting priorities for regional conservation planning in the mediterranean sea. Plos One 8(4): e59038. doi:10.1371/journal.pone.0059038.

Millot, C., 1999. Circulation in the western mediterranean sea. Journal of Marine Systems 20, 423-442.

Millot, C., Taupier-Letage, I., 2005. Circulation in the Mediterranean Sea. In: Saliot, A. (Ed.), The Handbook of Environmental Chemistry 5 (K). Springer-Verlag,Heidelberg, pp. 29-66.

Millot, C., Taupier-Letage, I., Benzohra, M., 1990. The Algerian eddies. Earth-Science Reviews 27, 203-219.

Mkhinini, N., Coimbra, A. L. S., Stegner, A., Arsouze, T., Taupier-Letage, I., Béranger, K., 2014. Long-lived mesoscale eddies in the eastern Mediterranean Sea: Analysis of 20 years of AVISO geostrophic velocities. Journal of Geophysical Research: Oceans 119, 8603-8626.

Mouillot, D., Albouy, C., Guilhaumon, F., Ben Rais Lasram, F., Coll, M., Devictor, V., Meynard, C., Pauly, D., Tomasini, J., Troussellier, M., Velez, L., Watson, R., Douzery, E., Mouquet, N., 2011. Protected and Threatened Components of Fish Biodiversity in the Mediterranean Sea. Current Biology, 21, 1044-1050. 
Moutin, T., Van Wambeke, F., Prieur, L., 2012. Introduction to the Biogeochemistry from the Oligotrophic to the Ultraoligotrophic Mediterranean (BOUM) experiment. Biogeosciences, 9, 3817-3825.

Morel, A., André, J.M., 1991. Pigment distribution and primary production in the western mediterranean as derived and modeled from coastal zone color scanner observations. Journal of Geophysical Research: Oceans 96, 12685-12698.

Mozetič, P., Solidoro, C., Cossarini, G., Socal, G., Precali, R., Francé, J., Bianchi, F., Vittor, C., Smodlaka, N., Fonda Umani, S., 2010. Recent trends towards oligotrophication of the Northern Adriatic: evidence from Chlorophyll a time series. Estuaries and Coasts 33, 362-375.

Muñoz, M., Reul, A., Plaza, F., Gómez-Moreno, M.L., Vargas-Yañez, M., Rodríguez, V., Rodríguez, J., 2015. Implication of regionalization and connectivity analysis for marine spatial planning and coastal management in the gulf of cadiz and alboran sea. Ocean \& Coastal Management 118, Part A, 60-74. Coastal systems under change.

NAOS-Med Team, 2012. Roadmap for the deployment decision of the NAOS Bio-Argo Mediterranean floats. Technical report available at http://en.naos-equipex.fr/content/download/65505/877517/file/Roadmap_Bio_Argo_NAOS_dec20121.pdf?version=1

Nowaczyk, A., Carlotti, F., Thibault-Botha, D., Pagano, M., 2011. Distribution of epipelagic metazooplankton across the Mediterranean Sea during the summer BOUM cruise. Biogeosciences, 8, 2159-2177.

Nieblas, A.E., Drushka, K., Reygondeau, G., Rossi, V., Demarcq, H., Dubroca, L., Bonhommeau, S., 2014. Defining mediterranean and black sea biogeochemical subprovinces and synthetic ocean indicators using mesoscale oceanographic features. Plos One 9(10) e111251. doi:10.1371/journal.pone.0111251.

Oke, P.R., Sakov, P., 2012. Assessing the footprint of a regional ocean observing system. Journal of Marine Systems, 105, $30-51$. Oliver, M.J., Irwin, A.J., 2008. Objective global ocean biogeographic provinces. Geophysical Research Letters,35, L15601.

Özsoy, E., Hecht, A., Ünlüata, , Brenner, S., Sur, H., Bishop, J., Latif, M., Rozentraub, Z., Ouz, T., 1993. A synthesis of the levantine basin circulation and hydrography, 1985-1990. Deep Sea Research Part II: Topical Studies in Oceanography 40, 1075-1119.

Palmiéri, J., 2014. Modélisation biogéochimique de la mer Méditerranée avec le modèle régional couplé NEMO-MED12/PISCES. Ph.D. thesis. Université Versailles-Saint-Quentin.

Pasqueron de Fommervault, O., D’Ortenzio, F., Mangin, A., Serra, R., Migon, C., Claustre, H., Lavigne, H., Ribera d'Alcalà, M., Prieur, L., Taillandier, V., Schmechtig, C., Poteau, A., Leymarie, E., Dufour, A., Besson, F., Obolensky, G., 2015. Seasonal variability of nutrient concentrations in the mediterranean sea: Contribution of bio-argo floats. Journal of Geophysical Research: Oceans 120, 8528-8550.

Planque, B., Lazure, P., Jegou, A.M., 2006. Typology of hydrological structures modelled and observed over the Bay of Biscay shelf. Scientia Marina 70, No S1.

Piante C., Ody D., 2015. Blue Growth in the Mediterranean Sea: the Challenge of Good Environmental Status. MedTrends Project. WWF-France. 192 pages.

Pınarbaşı, K., Galparsoro, I., Borja, Á., Stelzenmüller, V., Ehler, C. N., Gimpel, A., 2017. Decision support tools in marine spatial planning: Present applications, gaps and future perspectives. Marine Policy, 83, 83-91.

Poulain, P.M., Barbanti, R., Font, J., Cruzado, A., Millot, C., Gertman, I., Griffa, A., Molcard, A., Rupolo, V., Le Bras, S., Petit de la Villeon, L., 2007. Medargo: a drifting profiler program in the mediterranean sea. Ocean Science 3, 379-395.

Poulos, S. E., Drakopoulos, P. G., Collins, M. B., 1997. Seasonal variability in sea surface oceanographic conditions in the Aegean Sea (Eastern Mediterranean): an overview. Journal of Marine Systems,13(1), 225-244.

Prieur, L., Sournia, A., 1994. 'Almofront-1' (April-May 1991): an interdisciplinary study of the Almeria-Oran geostrophic front, SW Mediterranean Sea. Journal of Marine Systems 5, 187-203. Processes and Fluxes in the Geostrophic AlmeriaOran Front.

Psarra, S., Tselepides, A., Ignatiades, L., 2000. Primary productivity in the oligotrophic Cretan Sea (NE Mediterranean): seasonal and interannual variability. Progress in Oceanography 46, 187-204.

Puillat, I., Taupier-Letage, I., Millot, C., 2002. Algerian Eddies lifetime can near 3 years. Journal of Marine Systems 31, $245-259$. 
Pujo-Pay, M., Conan, P., Oriol, L., Cornet-Barthaux, V., Falco, C., Ghiglione, J.-F., Goyet, C., Moutin, T., Prieur, L., 2011. Integrated survey of elemental stoichiometry (C, N, P) from the western to eastern Mediterranean Sea, Biogeosciences, 8, 883-899.

QGIS Development Team, 2009. QGIS Geographic Information System. Open Source Geospatial Foundation.

R Core Team, 2015. R: A Language and Environment for Statistical Computing. R Foundation for Statistical Computing. Vienna, Austria.

Raymond, B., 2014. Pelagic regionalisation, in: De Broyer, C., Koubbi, P., Griffiths, H., Raymond, B., d'Udekem d'Acoz, C., Van de Putte, A., Danis, B., David, B., Grant, S., Gutt, J., Held, C., Hosie, G., Huettmann, F., Post, A., Ropert-Coudert, Y. (Eds.), Biogeographic Atlas of the Southern Ocean. Scientific Committee on Antarctic Research, Cambridge UK, pp. 418-421.

Reygondeau, G., Guieu, C., Benedetti, F., Irisson, J.O., Ayata, S.D., Gasparini, S., Koubbi, P., 2017. Biogeochemical regions of the mediterranean sea: An objective multidimensional and multivariate environmental approach. Progress in Oceanography 151, 138-148.

Reygondeau, G., J.-O., I., Ayata, S., Gasparini, S., Benedetti, F., Albouy, C., Hattab, T., Guieu, C., Koubbi, P., 2014. Definition of the Mediterranean eco-regions and maps of potential pressures in these eco-regions. Technical Report. Deliverable Nr. 1.6. FP7-PERSEUS project.

Rinaldi, E., Buongiorno Nardelli, B., Zambianchi, E., Santoleri, R., Poulain, P.M., 2010. Lagrangian and Eulerian observations of the surface circulation in the Tyrrhenian Sea. Journal of Geophysical Research: Oceans 115. C04024.

Roether, W., Klein, B., Manca, B. B., Theocharis, A., Kioroglou, S., 2007. Transient Eastern Mediterranean deep waters in response to the massive dense-water output of the Aegean Sea in the 1990s. Progress in Oceanography 74, 540-571.

Rossi, V., Ser-Giacomi, E., Lòpez, C., Hernàndez-Garcìa, E., 2014. Hydrodynamic provinces and oceanic connectivity from a transport network help designing marine reserves. Geophysical Research Letters 41 (8), 2883-2891.

Sathyendranath, S., Longhurst, A., Caverhill, C. M., Platt, T., 1995. Regionally and seasonally differentiated primary production in the North Atlantic. Deep Sea Research Part I: Oceanographic Research Papers 42, 1773-1802.

Ser-Giacomi, E., Rossi, V., Lopez, C. \& Hernandez-Garcia, E., 2015. Flow networks: a characterization of geophysical fluid transport. Chaos, 25, 036404.

Seguin, G., Errhif, A., Dallot, S., 1994. Diversity and structure of pelagic copepod populations in the frontal zone of the eastern Alboran Sea. Hydrobiologia, 292/293, 369-377.

Siokou-Frangou, I., Bianchi, M., Christaki, U., Christou, E., Giannakourou, A., Gotsis, O., Ignatiades, L., Pagou, K., Pitta, P., Psarra, S., Souvermezoglou, E., Wambeke, F. V., Zervakis, V., 2002. Carbon flow in the planktonic food web along a gradient of oligotrophy in the Aegean Sea (Mediterranean Sea) Journal of Marine Systems 33-34, 335-353.

Siokou-Frangou, I., Christaki, U., Mazzocchi, M. G., Montresor, M., Ribera d'Alcalá, M., Vaqué, D., Zingone, A., 2010. Plankton in the open Mediterranean Sea: a review. Biogeosciences 7(5), 1543-1586.

Siokou-Frangou, I., Zervoudaki, S., Christou, E. D., 2013. Mesozooplankton community distribution down to $1000 \mathrm{~m}$ along a gradient of oligotrophy in the Eastern Mediterranean Sea (Aegean Sea) Journal of Plankton Research 35, 1313-1330.

Spalding, M., Fox, H., Allen, G., Davidson, N., Ferdana, Z., Finlayson, M., Halpern, B., Jorge, M., Lombana, A., Lourie, S., Martin, K., McManus, E., Molnar, J., Recchia, C., Robertson, J., 2007. Marine ecoregions of the world: a bioregional- ization of coastal and shelf areas. Bioscience 57(7), 573-582.

Spillman, C., Imberger, J., Hamilton, D., Hipsey, M., Romero, J., 2007. Modelling the effects of Po River discharge, internal nutrient cycling and hydrodynamics on biogeochemistry of the Northern Adriatic Sea. Journal of Marine Systems 68, 167-200. 
The MerMex Group: de Madron, X.D., Guieu, C., Sempere, R., Conan, P., Cossa, D., D’Ortenzio, F., Estournel, C., Gazeau, F., Rabouille, C., Stemmann, L., Bonnet, S., Diaz, F., Koubbi, P., Radakovitch, O., Babin, M., Baklouti, M., BanconMontigny, C., Belviso, S., Bensoussan, N., Bonsang, B., Bouloubassi, I., Brunet, C., Cadiou, J.F., Carlotti, F., Chami, M., Charmasson, S., Charriere, B., Dachs, J., Doxaran, D., Dutay, J.C., Elbaz-Poulichet, F., Eleaume, M., Eyrolles, F., Fernandez, C., Fowler, S., Francour, P., Gaertner, J.C., Galzin, R., Gasparini, S., Ghiglione, J.F., Gonzalez, J.L., Goyet, C., Guidi, L., Guizien, K., Heimbuerger, L.E., Jacquet, S.H.M., Jeffrey, W.H., Joux, F., Le Hir, P., Leblanc, K., Lefevre, D., Lejeusne, C., Leme, R., Loye-Pilot, M.D., Mallet, M., Mejanelle, L., Melin, F., Mellon, C., Merigot, B., Merle, P.L., Migon, C., Miller, W.L., Mortier, L., Mostajir, B., Mousseau, L., Moutin, T., Para, J., Perez, T., Petrenko, A., Poggiale, J.C., Prieur, L., Pujo-Pay, M., Pulido-Villena, Raimbault, P., Rees, A.P., Ridame, C., Rontani, J.F., Pino, D.R., Sicre, M.A., Taillandier, V., Tamburini, C., Tanaka, T., Taupier-Letage, I., Tedetti, M., Testor, P., Thebault, H., Thouvenin, B., Touratier, F., Tronczynski, J., Ulses, C., Van Wambeke, F., Vantrepotte, V., Vaz, S., Verney, R., 2011. Marine ecosystems' responses to climatic and anthropogenic forcings in the Mediterranean. Progress in Oceanography 91 , 97-166.

Theocharis, A., Balopoulos, E., Kioroglou, S., Kontoyiannis, H., lona, A., 1999. A synthesis of the circulation and hydrography of the south Aegean Sea and the straits of the Cretan Arc (March 1994-January 1995). Progress in Oceanography 44, 469-509.

Thibault, D., Gaudy, R., Le Fèvre, J., 1994. Zooplankton biomass, feeding and metabolism in a geostrophic frontal area (AlmeriaOran front, western Mediterranean). Significance to pelagic food webs. Journal of Marine Systems, 5, $297-311$.

Tsiaras, K. P., Petihakis, G., Kourafalou, V. H., Triantafyllou, G., 2014. Impact of the river nutrient load variability on the North Aegean ecosystem functioning over the last decades. Journal of Sea Research, 86, 97-109.

Uitz, J., Stramski, D., Gentili, B., D'Ortenzio, F., Claustre, H., 2012. Estimates of phytoplankton class-specific and total primary production in the Mediterranean Sea from satellite ocean color observations. Global Biogeochemical Cycles 26(2), GB2024. doi:10.1029/2011GB004055.

Van Leeuwen, S., Tett, P., Mills, D., Van der Molen, J., 2015. Stratified and non-stratified areas in the North Sea: Long-term variability and biological and policy implications. Journal of Geophysical Research : Oceans, 120, 1-17.

Vetrano, A., Napolitano, E., lacono, R., Schroeder, K., Gasparini, G.P., 2010. Tyrrhenian Sea circulation and water mass fluxes in spring 2004: Observations and model results. Journal of Geophysical Research: Oceans 115. C06023.

Videau, C., Sournia, A., Prieur, L., Fiala, M., 1994. Phytoplankton and primary production characteristics at selected sites in the geostrophic almeria-oran front system (SW Mediterranean Sea). Journal of Marine Systems 5, 235-250. Processes and Fluxes in the Geostrophic Almeria-Oran Front.

Viudez, A., Tintoré, J., 1995. Time and space variability in the eastern alboran sea from march to may 1990. Journal of Geophysical Research 100, 8571-8586.

Volpe, G., Buongiorno Nardelli, B., Cipollini, P., Santoleri, R., Robinson, I.S., 2012. Seasonal to interannual phytoplankton response to physical processes in the Mediterranean Sea from satellite observations. Remote Sensing of Environment, 117, 223-235,

Youssara, F., Gaudy, R., 2001. Variations of zooplankton in the frontal area of the Alboran Sea (Mediterranean sea) in winter 1997. Oceanologica Acta, 24, 361-376 


\section{Figure captions}

Figure 1: Map of the Mediterranean region displaying the main seas, locations, and surface circulation features, with a special focus on those cited in the text (circulation redrawn from Millot and TaupierLetage, 2005).

Figure 2: Representation of the eight regionalisations of the Mediterranean Sea compared in this study (post-processed for clarity, as described below). Colours are used to differentiate regions; they have no special meaning among panels. These maps (and all the following ones) can be explored interactively at https://mermexregio.obs-vlfr.fr.

Figure 3: Map of the congruence of frontiers among regionalisations. The colour scale depicts the number of regionalisations that define a given pixel as a frontier between two regions. If all regional frontiers agree, the frontier congruence value would be 8 ; the maximal observed frontier congruence value was 5 .

Figure 4: Map of smoothed frontier congruence overlaid with the eleven consensus regions (white polygons), defined as having a low congruence core and being surrounded by strong frontiers, and the nine consensus frontiers (dashed lines), defined as having a high congruence core and some spatial extent.

Figure 5: Consensus regions and frontiers overlaid on a) the cumulative human impacts on the Mediterranean Sea, from Micheli et al. (2013a) and b) the frequency of inclusion in spatial conservation plans, from Micheli et al. (2013b). Map (a) cumulates 22 anthropogenic drivers, whether direct (e.g., fisheries, shipping, coastal population density) or indirect (e.g., acidification, sea surface warming, hypoxia). Map (b) considers six existing and twelve proposed conservation plans in the Mediterranean Sea (data kindly provided by the authors).

Figure 6: Average number of observations used to compute the climatologies of classic hydrological and biogeochemical variables between 0 and $100 \mathrm{~m}$ in the World Ocean Atlas (WOA; since 1955, downloaded from http://data.nodc.noaa.gov/thredds/dodsC/woa/WOA13/DATAv2/). NB: the colour scale is not linear, otherwise the map would be dominated by a few pixels with very dense data which are not representative of the overall sampling effort in the basin.

\section{Table caption}

Table 1: Synthesis of the data sources, resolution, and processing for the statistical regionalisations considered in this review. See Sup Figure 1 for a representation of all the raw regionalisations. 


\section{Supplementary figure captions}

Sup Fig 1: Original regions.

Sup Fig 2: Gridded regions.

Sup Fig 3: Filtered regions.

Sup Fig 4: Analysis of the sensitivity of consensus regions (white) and frontiers outlines (red) to the smoothing radius $(0.45 \circ, 0.5 \circ$, and $0.55 \circ \sim 45 \mathrm{~km}, 50 \mathrm{~km}$, and $55 \mathrm{~km}$ ) and the contour level value (levels $0.28,0.3$, and 0.32 for regions; levels $0.78,0.8,0.82$ for frontiers). Most contour lines are superposed and vary little between panels, showing that the congruence surface is steep in these regions and that the actual value chosen has little consequence on the regions outlines. Some notable changes are: (i) several frontiers disappear at the highest smoothing level, which is expected because thin features such as frontiers would get smoothed out. This shows that a high smoothing level is not appropriate for our purpose. (ii) Some regions are connected to adjacent zones of low congruence at some contour levels (West Algeria being connected to East Algeria, North Ionian being extended). In both case the connections are thin and the core of the consensus regions are not in those adjacent regions; this is the reason why they are not considered. 


\begin{tabular}{|c|c|c|c|c|c|c|c|c|c|}
\hline Study & Variables & Type & $\begin{array}{l}\text { Data } \\
\text { Period }\end{array}$ & $\begin{array}{l}\text { Temporal } \\
\text { resolution }\end{array}$ & Spatial resolution & Source & Preparation & $\begin{array}{l}\text { Regionalisation } \\
\text { Clustering method }\end{array}$ & $\begin{array}{l}\text { Number of } \\
\text { identified } \\
\text { regions }\end{array}$ \\
\hline $\begin{array}{l}\text { D'Ortenzio \& } \\
\text { Ribera d'Alcala } \\
\text { (2009) }\end{array}$ & Surface chlorophyll concentration & Satellite data & $\begin{array}{l}10 \text { years (1998- } \\
\text { 2008) }\end{array}$ & 8 days & $9 \mathrm{~km}$ & SeaWiFS & $\begin{array}{l}\text { Normalized } \\
\text { climatology }\end{array}$ & $\mathrm{K}$-means & 7 \\
\hline $\begin{array}{l}\text { Mayot et al. } \\
\text { (2016) }\end{array}$ & Surface chlorophyll concentration & Satellite data & $\begin{array}{c}16 \text { years }(1998- \\
2014)\end{array}$ & 8 days & $9 \mathrm{~km}$ & $\begin{array}{l}\text { SeaWiFS \& MODIS } \\
\text { Aqua (Level 3) }\end{array}$ & $\begin{array}{l}\text { Normalized } \\
\text { climatology }\end{array}$ & K-means & $\begin{array}{l}7 \text { for } \\
\text { climatologies, } \\
12 \text { for annual } \\
\text { clusters }\end{array}$ \\
\hline Palmiéri (2004) & Vertically-integrated chlorophyll concentration & Modelled data & $\begin{array}{c}8 \text { years }(1997- \\
2005)\end{array}$ & 1 month & $1 / 12^{\circ}(6-8 \mathrm{~km})$ & $\begin{array}{l}\text { NEMO MED12- } \\
\text { PISCES model }\end{array}$ & $\begin{array}{l}\text { Normalized } \\
\text { climatology }\end{array}$ & K-means & 4 \\
\hline $\begin{array}{l}\text { Reygondeau et } \\
\text { al. (2017) }\end{array}$ & $\begin{array}{l}16 \text { variables: temperature, salinity, chlorophyll } \\
\text { concentration, NO2, NO3, PO4, } \mathrm{SiO} 2 \text {, oxygen, } \\
\mathrm{pH} \text {, bathymetry (except for the epipelagic } \\
\text { regionalisation), flux of POC, euphotic depth, } \\
\text { thermocline depth and intensity, mixed layer } \\
\text { depth, wind speed }\end{array}$ & $\begin{array}{c}\text { Climatological } \\
\text { data }\end{array}$ & $\begin{array}{c}40 \text { years }(1960- \\
2000)\end{array}$ & NA & $20 \mathrm{~km}$ & MEDAR/ MEDATLAS & $\begin{array}{l}\text { Normalized } \\
\text { climatology }\end{array}$ & $\begin{array}{l}\text { Consensus of K- } \\
\text { means, C-means, } \\
\text { HCA Ward, HAC } \\
\text { complete (Olivier } \\
\text { et al. 2004) }\end{array}$ & $\begin{array}{l}11 \text { for pelagic } \\
\text { layers, } 24 \text { for } \\
\text { sea-floor }\end{array}$ \\
\hline $\begin{array}{l}\text { Berline et al. } \\
\text { (2014) }\end{array}$ & Lagrangian trajectories at 0,50 , and $100 \mathrm{~m}$ & Modelled data & $\begin{array}{c}3 \text { years }(2007- \\
2010)\end{array}$ & 1 day & $1 / 12^{\circ}(8 \mathrm{~km})$ & $\begin{array}{c}\text { Mercator PSY2V3 } \\
\text { model }\end{array}$ & $\begin{array}{l}\text { Mean connection } \\
\text { time matrix used as } \\
\text { distance matrix }\end{array}$ & $\begin{array}{l}\text { HCA flexible } \\
\text { (compared with } \\
\text { HCA Ward) }\end{array}$ & $\begin{array}{l}21 \text { (reduced to } \\
15 \text { here) }\end{array}$ \\
\hline $\begin{array}{l}\text { Rossi et al. } \\
\text { (2014) }\end{array}$ & Lagrangian trajectories at $8 \mathrm{~m}$ & Modelled data & $\begin{array}{l}10 \text { years }(2002- \\
2011) \text {, summer } \\
\text { and winter }\end{array}$ & $\begin{array}{c}\text { transport } \\
\text { duration of } 30 \\
\text { and } 60 \text { days }\end{array}$ & $\begin{array}{l}\text { velocity field: } 1 / 16 \\
\text { network: } 1 / 4^{\circ}\end{array}$ & Oddo et al. 2009 & $\begin{array}{l}\text { Network adjency } \\
\text { matrix, i.e. a } \\
\text { probabilistic } \\
\text { connectivity matrix }\end{array}$ & $\begin{array}{l}\text { Infomap (Rosvall } \\
\text { and Bergstrom, } \\
\text { 2008) }\end{array}$ & $\begin{array}{l}47 \text { for } 30 \text { days } \\
\text { (reduced to } 30 \\
\text { here), } 40 \text { for } \\
60 \text { days }\end{array}$ \\
\hline $\begin{array}{l}\text { Nieblas et al. } \\
\text { (2014) }\end{array}$ & $\begin{array}{l}\text { Classical variables: SST, surface chlorophyll } \\
\text { concentration, bathymetry; Mesoscale } \\
\text { variables: eddy kinetic energy, finite-size } \\
\text { Lyapunov exponents, Okubo-Weiss parameter, } \\
\text { SST and surface chlorophyll-a frontal gradients }\end{array}$ & $\begin{array}{c}\text { Climatological } \\
\text { data and } \\
\text { modelled data }\end{array}$ & $\begin{array}{c}8 \text { years }(2002- \\
2010)\end{array}$ & NA & $\begin{array}{l}\text { SST, chl, bathymetry } \\
\text { at } 4 \mathrm{~km} \text {; sea level } \\
\text { anomalies and } \\
\text { geostrophic currents } \\
\text { used to compute EKE, } \\
\text { FSLE, and OW were } \\
\text { extracted at } 1 / 3^{\circ} \text { and } \\
\text { regridded to } 4 \mathrm{~km}\end{array}$ & $\begin{array}{l}\text { SST: AVHRR; chl: } \\
\text { MODIS; Ssalto/Duacs } \\
\text { SLA/geostrophic } \\
\text { currents computed and } \\
\text { distributed by AVISO; } \\
\text { bathymetry: NOAA } \\
\text { ETOPO1 }\end{array}$ & $\begin{array}{l}\text { Normalized } \\
\text { climatologies of } \\
\text { three sets: classical, } \\
\text { mesoscale, classical } \\
\quad+\text { mesoscale }\end{array}$ & K-means & 5 \\
\hline $\begin{array}{l}\text { Reygondeau et } \\
\text { al. (2014) }\end{array}$ & $\begin{array}{l}\text { Distribution of more than } 800 \text { species based on } \\
\text { environmental niche model (ENFA, NPPEN, } \\
\text { Maxent, Domain, Bioclim) using } 16 \\
\text { environmental variables }\end{array}$ & Modelled data & $\begin{array}{l}40 \text { years }(1960- \\
2000)\end{array}$ & & $20 \mathrm{~km}$ & $\begin{array}{c}\text { physical and } \\
\text { biogeochemical } \\
\text { variables: MEDAR/ } \\
\text { MEDATLAS, biological } \\
\text { occurences: OBIS and } \\
\text { GBIF }\end{array}$ & $\begin{array}{l}\text { Weighted spatial } \\
\text { distribution }\end{array}$ & $\begin{array}{l}\text { Consensus of K- } \\
\text { means, C-means, } \\
\text { HCA Ward, HAC } \\
\text { complete (Olivier } \\
\quad \text { et al. 2004) }\end{array}$ & $\begin{array}{l}25 \text { with all } \\
\text { information, } 15 \\
\text { for only pelagic } \\
\text { data }\end{array}$ \\
\hline
\end{tabular}

\section{Cited references in the table}

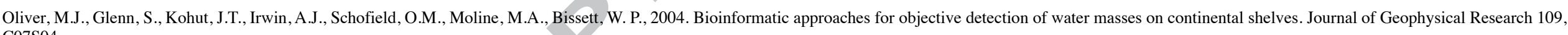
C07S04

Rosvall, M.,Bergstrom, C.T., 2008. Maps of random walks on complex networks reveal community structure. Proc. Natl. Acad. Sci. U.S.A. 105(4), 1118-1123. 